\title{
REVIEW ARTICLE Temporal and spatial control of gene expression in horticultural crops
}

\author{
Manjul Dutt ${ }^{1}$, Sadanand A Dhekney ${ }^{2}$, Leonardo Soriano ${ }^{1,3}$, Raju Kandel ${ }^{2}$ and Jude W Grosser ${ }^{1}$
}

Biotechnology provides plant breeders an additional tool to improve various traits desired by growers and consumers of horticultural crops. It also provides genetic solutions to major problems affecting horticultural crops and can be a means for rapid improvement of a cultivar. With the availability of a number of horticultural genome sequences, it has become relatively easier to utilize these resources to identify DNA sequences for both basic and applied research. Promoters play a key role in plant gene expression and the regulation of gene expression. In recent years, rapid progress has been made on the isolation and evaluation of plant-derived promoters and their use in horticultural crops, as more and more species become amenable to genetic transformation. Our understanding of the tools and techniques of horticultural plant biotechnology has now evolved from a discovery phase to an implementation phase. The availability of a large number of promoters derived from horticultural plants opens up the field for utilization of native sequences and improving crops using precision breeding. In this review, we look at the temporal and spatial control of gene expression in horticultural crops and the usage of a variety of promoters either isolated from horticultural crops or used in horticultural crop improvement.

Horticulture Research (2014) 1, 14047; doi:10.1038/hortres.2014.47; Published online: 24 September 2014

\section{INTRODUCTION}

Gene expression in prokaryotes as well as in eukaryotes is regulated quantitatively and qualitatively by specific upstream DNA sequences. ${ }^{1}$ These DNA sequences are commonly known as gene promoters. Initiation of transcription is in turn mediated by proteins that recognize specific DNA sequences in the promoter, thereby inducing RNA polymerase activity. 2,3 Promoters regulate gene expression through DNA recognition sequences, which interact with basic transcription initiation complexes and numerous transcription factors. ${ }^{4}$ Such DNA recognition sequences usually include a core promoter with upstream enhancer sequences located close to the structural portion of the gene. ${ }^{2}$ Transcription can be activated by these enhancer sequences independent of their location, distance or orientation with respect to the genes promoters. ${ }^{5}$

Promoters in general are divided into two regions: a core promoter region and upstream regulatory regions. ${ }^{6}$ The core promoter consists of a 50-100 bp sequence adjacent to the transcription initiation site and flanking sequences. ${ }^{\text {T }}$ This region interacts with the general transcription machinery ${ }^{8}$ and ensures the accurate initiation of transcription by RNA polymerase II. ${ }^{9}$ The core promoter consists of two key genetic elements: the TATA box (present in most promoters) and/or an initiator (Inr) element overlapping the transcription start site. ${ }^{10,11}$ The initiator element binds trans-acting factors for the placement of the start site ${ }^{12-14}$ and can also mediate transcription initiation in some TATA-less promoters. ${ }^{15,16}$ The upstream promoter regions of $1-2 \mathrm{~kb}$ or more contains several cis-regulatory elements that serve as the binding sites for genespecific regulators. ${ }^{7}$ The regulatory sequences that play a role in the qualitative specificity of gene expression have been intensely studied. ${ }^{17-19}$ Several regulatory sequences present upstream of the $5^{\prime}$ region of plant genes include multiple cis-regulatory elements whose distribution and presence contribute to the expression pattern of that particular gene. This interaction between the cis- acting elements and the transcription factors is key in the regulation of gene expression. ${ }^{20}$ The presence of several cis-acting elements can contribute to the complex expression profile of a particular gene $^{2}$ and their differential combinatorial interactions with the transcription factors result in expression of the adjacent gene to be either constitutive, induced by external factors, tissue-specific or some combination of these. ${ }^{21,22}$

The first biotech crop commercialized in the United States was a horticultural commodity: the Flavr Savr tomato, which was submitted for approval in 1992 and released for consumption in $1994 .^{23-25}$ Numerous horticultural crops in the last 20 years have since been transformed with a wide range of genes and promoter elements. In most studies the introduced genes are controlled by constitutive promoters-the most popular being the 35S promoter obtained from the Cauliflower mosaic virus (CaMV). ${ }^{26,27}$ In many cases, constitutive gene expression may not be required, especially when this does not serve a beneficial purpose. ${ }^{28,29}$ In such cases, targeted gene expression using tissue-specific or inducible promoters can often provide advantages not seen using constitutive promoters. ${ }^{30}$ In recent years, there has been a boom in the availability of promoter information in many promoter databases. ${ }^{31-33}$ This wealth of information enables the researcher to better understand the role of promoters and their control on plant growth and development. It also allows for the development of improved cultivars containing desirable traits. ${ }^{34,35}$ In this review, we look at the different promoter elements either isolated from horticultural crops or used to genetically modify a horticultural crop for improved traits (Table 1 ).

\section{PROMOTERS USED FOR CONSTITUTIVE GENE EXPRESSION}

Constitutive promoters direct gene expression uniformly in most tissues and cells at all stages of plant growth and development. Constitutive promoters confer high levels of transgene expression when transferred to plant cells. They generally consist of a core DNA

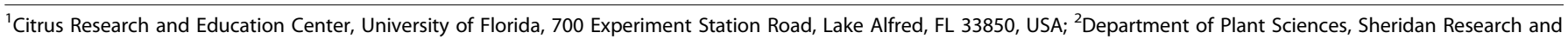
Extension Center, University of Wyoming, Sheridan, WY 82801, USA and ${ }^{3}$ Universidade de Sao Paulo, Centro de Energia Nuclear na Agricultura, Piracicaba, Brazil

Correspondence: M Dutt (manjul@ufl.edu)

Received: 25 June 2014; Revised: 19 July 2014; Accepted: 6 August 2014 
Table 1 Description of the promoter fragments either isolated from horticultural crops or used to genetically modify a horticultural crop for improved traits

\begin{tabular}{|c|c|c|c|}
\hline Promoter & Origin & Crop use & References \\
\hline \multicolumn{4}{|l|}{ Constitutive expression } \\
\hline BSV & Banana streak badnavirus & Banana, Sunflower & 96 \\
\hline CaMV 35S & Cauliflower mosaic virus & $\begin{array}{l}\text { Apple, broccoli, citrus, chrysanthemum, cocoa, } \\
\text { collard, grape, Indian Mustard, Lilium, Nicotiana } \\
\text { glutinosa, papaya, peach, petunia, plum, poplar, } \\
\text { rose, strawberry, tomato, torenia }\end{array}$ & $41-44,47-63,65-79,84,85,87$ \\
\hline CMPS & Cestrum Yellow Leaf curling virus & Grape & 95 \\
\hline Lhca3.St.1 & Potato & Chrysanthemum & 100 \\
\hline Mannopin synthase & Gladiolus & Gladiolus & 99 \\
\hline RolD & A. rhizogenes & Gladiolus & 99 \\
\hline Uep1 & Oilpalm & Oilpalm, tobacco & 98 \\
\hline Ubiquitin & Grape, gladiolus & Grape, gladiolus & 49,99 \\
\hline \multicolumn{4}{|l|}{ Fruit-specific expression } \\
\hline ACC-oxidase & Peach, apple, tomato, banana & Tomato, banana & 104-107 \\
\hline ADP-glucose pyrophosphorylase & Watermelon & Tomato & 115 \\
\hline Expansin & Cherry, cucumber & Tomato, cucumber & 109,110 \\
\hline Cucumisin & Melon & Melon & 114 \\
\hline C11 & Citrus & Lemon & 117 \\
\hline CsACS1G/CsACS1 & Cucumber & Arabidopsis & 111 \\
\hline CsExp & Cucumber & Cucumber & 110 \\
\hline DefH9 & Grape & Grape & 138 \\
\hline DFR & Grape & Grape & 124 \\
\hline E8 & Tomato & Tomato & 133 \\
\hline Faxyl1 & Strawberry & Strawberry & 112 \\
\hline GIZEP & Gentiana lutea & Tomato & 126 \\
\hline Metallothionin & Citrus, oilpalm & Arabidopsis & 118,119 \\
\hline Pac1 & Yeast & Avocado & 136 \\
\hline RolB & A. rhizogenes & Tomato & 134 \\
\hline SPS & Banana & Banana & 116 \\
\hline SIACS4/SIEXP1 & Tomato & Tomato & 127 \\
\hline \multicolumn{4}{|l|}{ Seed-specific expression } \\
\hline $2 S$ & Grape & Grape, tobacco & 145,147 \\
\hline CuMFT1 & Citrus & Arabidopsis & 171 \\
\hline Dc3 & Carrot & Arabidopsis & 163 \\
\hline HaG3-A & Sunflower & Tobacco & 170 \\
\hline LeB4 & Vicia faba & Tobacco & 156 \\
\hline LegA & Pea & Helianthus & 143 \\
\hline NapA & Brassica napus & Tobacco & 150 \\
\hline Phas & Bean & Tobacco & 140,172 \\
\hline Psl & Pea & Tobacco & 168 \\
\hline Str & Catharanthus roseus & Tobacco & 173 \\
\hline USP & Vicia faba & Tomato & 158 \\
\hline \multicolumn{4}{|l|}{ Floral tissue-specific expression } \\
\hline BAN215-6 & Brassica campestris & Tobacco & 249 \\
\hline $\mathrm{CHS}$ & Bean & Petunia, tobacco & 197, 198 \\
\hline END1 & Pea & Tobacco & 250 \\
\hline GTCHS1 & Gentiana triflora & Petunia & 210 \\
\hline LAT52 & Tomato & Lilium longiflorum & 246 \\
\hline PsTL1 & Pyrus serotina & Tobacco & 214 \\
\hline SK2 & Potato & Potato & 224 \\
\hline TomA108 & Tomato & Tobacco & 248 \\
\hline \multicolumn{4}{|l|}{ Root-specific expression } \\
\hline B33 & Potato & Potato & 284 \\
\hline FaRB7 & Strawberry & Tobacco & 267 \\
\hline Glb3 5' & Sesbania rostrata & Lotus & 273 \\
\hline MipB & Mesembryanthemum crystallinum & Tobacco & 268 \\
\hline Npv30 & Bean & Lotus & 275 \\
\hline PsENOD12A/PsENOD12B & Pea & Vicia hirsuta & 274 \\
\hline RB7 & Tobacco & Tomato & 267 \\
\hline SLREO & Tomato & Tomato & 263 \\
\hline VfLb29 & Vicia faba & Vicia faba & 271 \\
\hline Sporamin & Sweet potato & Potato, tobacco & 287,288 \\
\hline
\end{tabular}


Table 1 Continued

\begin{tabular}{|c|c|c|c|}
\hline Promoter & Origin & Crop use & References \\
\hline AtSUC2 & Arabidopsis & Citrus, pear, strawberries & $307,309,310$ \\
\hline CoYMVP & Commelina Yellow Mottle Virus & Apple & 313 \\
\hline CsPP2 & Citrus & Sweet orange & 308 \\
\hline CsSUS1p & Citrus & Arabidopsis/tobacco & 311 \\
\hline GRP 1.8 & Bean & Tobacco & 300 \\
\hline GS3A & Pea & Alfalfa & 305 \\
\hline PAL2 & Bean & Tobacco & 302 \\
\hline RolC & A. rhizogenes & Apple & 313 \\
\hline RTBV & Rice Tungro Virus & Citrus & 307 \\
\hline Rice sucrose synthase I & Rice & Citrus & 307 \\
\hline \multicolumn{4}{|l|}{ Inducible expression } \\
\hline $4 C L$ & Parsley/tobacco & Parsley/tobacco & 352 \\
\hline CM-ACO1 & Melon & Tobacco & 351 \\
\hline HSP & Tomato & Sunflower & 344 \\
\hline Lehsp23.8 & Tomato & Tomato & 341 \\
\hline Pinll & Potato & Alfalfa, Nicotiana plumbaginifolia, rice & 334-336 \\
\hline PR-1 & Tobacco & Broccoli & 353 \\
\hline PR 10 & Alfalfa & Grape & 354 \\
\hline Prosystemin & Tomato & Tomato & 323 \\
\hline $\mathrm{Rd} 29 \mathrm{~A}$ & Arabidopsis & Potato & 350 \\
\hline SWPA2 & Sweet potato & Tobacco & 349 \\
\hline Wun1 & Potato & Tobacco & 340 \\
\hline
\end{tabular}

sequence (core promoter) along with other regulatory elements such as enhancers, silencers and other DNA sequences, which interact with DNA binding proteins (transcription factors) to drive transgene expression in various plant cells. ${ }^{27}$ Constitutive promoters may provide ectopic gene expression in transgenic plants, not otherwise observed under normal conditions. Significantly variable results may be observed from the use of a constitutive promoter in a monocotyledonous and dicotyledonous species, which makes it essential to identify candidate promoters for specific groups to ensure high transgene expression levels. ${ }^{36}$ Most constitutive promoters used for production of transgenic plants derive their origin from viral sequences. Advances in plant genome sequencing initiatives and availability of public genomic databases have led to the identification of numerous plant-derived constitutive promoters, which are increasingly being used in plant transformation.

The Cauliflower mosaic virus 35S (CaMV 35 S or simply 35S) promoter is by far the most widely used promoter in plant transformation. ${ }^{37}$ The promoter is capable of conferring high gene expression levels in most cells when transferred to plants. ${ }^{38}$ The 355 promoter has been extensively studied to identify key regulatory sequences that function to provide high gene expression levels. ${ }^{27}$ Sequences analyses of the $35 \mathrm{~S}$ promoter reveal the presence of several regulatory elements that are dispersed among the entire promoter length. The promoter consists of two domains $A$ and $B$, which are further subdivided into several subdomains. ${ }^{27}$ Deletion analyses studies identified specific cis-elements in these subdomains that confer expression in specific tissues of above and below-ground plant parts. Various combinations of cis-elements of the 35S promoter can produce gene expression patterns that are not observed with the sole use of such elements, which suggests an interaction between cis-elements for expression at various plant growth and developmental stages. ${ }^{27}$ Although the $35 \mathrm{~S}$ promoter is considered to direct constitutive expression, varied expression effects result from its interaction with environmental factors ${ }^{39}$ and physiological state of plant development. ${ }^{40}$ Gene expression by the $35 \mathrm{~S}$ promoter also appears to be species-dependent. For instance, high GUS expression levels were observed in pollen of transgenic strawberry plants when a $35 \mathrm{~S}$ promoter was used, but no expression could be detected in transgenic tomato or petunia plants with similar construct configurations. ${ }^{41-43}$ In other cases, transgenic chrysanthemum expressing a GUS gene under the control of the $35 \mathrm{~S}$ promoter exhibited weak transgene expression levels. ${ }^{44}$

In-depth functional analyses of regulatory elements present in the $35 \mathrm{~S}$ promoter has increased our understanding of the role of individual cis and enhancer elements in driving gene transcription. ${ }^{27,45}$ Such information has been exploited to produce chimeric versions of the $35 \mathrm{~S}$ promoter that contain duplicated cis or enhancer elements. ${ }^{46}$ Inclusion of additional viral- and plant-derived sequences in various combinations can provide additional synergy to the $35 \mathrm{~S}$ promoter. Duplication of $35 \mathrm{~S}$ enhancer elements in unique orientation along with the core promoter can greatly assist in driving high levels of several genes in a single transformation cassette. ${ }^{47}$

Genetic constructs containing a 35S-derived core promoter and either single or duplicated enhancer elements that controlled fusion gene expression, were arranged in a unidirectional (tandem) or bidirectional (divergent) orientation. Significantly high levels of GFP and GUS expression was observed in grapevine somatic embryos and plants transformed with constructs containing a bidirectional duplex promoter complex, where core promoters and duplicated enhancer elements were arranged in a divergent orientation. This phenomenon was attributed to synergistic activity of core promoters and enhancers arranged in a unique orientation. ${ }^{48}$ Similar results were obtained when a grapevine MybA1 transcription factor encoding anthocyanin expression was fused to viral promoters in various arrangements. ${ }^{49}$

The $35 \mathrm{~S}$ promoter has been extensively used in horticultural crops for improving abiotic and biotic stress tolerance and quality traits, and for modification of plant architecture. Transgenic papaya that expressed a viral coat protein gene driven by a $35 \mathrm{~S}$ promoter exhibited enhanced resistance against papaya ring spot virus resistance.$^{50}$ Following extensive field trials to confirm stability of resistance, the transgenic lines were used in breeding programs to produce virus resistant cultivars, which were deregulated and released for commercial production. ${ }^{51}$ Transgenic 'Honey Sweet' plums expressing a plum pox virus coat protein under the control of the $35 \mathrm{~S}$ promoter exhibited enhanced resistance to plum pox virus, the causal agent of Sharka disease of plum. ${ }^{52,53}$ 'Honey Sweet' 
was cleared for commercial production in the United States in 2010 following extensive studies by appropriate regulatory agencies. ${ }^{54}$ Similar strategies have been used to incorporate virus resistance in other fruit and vegetable crops. ${ }^{55,56}$

The $35 \mathrm{~S}$ promoter has also been fused to a number of genes coding for antimicrobial proteins to improve fungal and bacterial resistance. Improved scab resistance was demonstrated in transgenic apple that expressed a mbr4 gene driven by the $35 \mathrm{~S}$ promoter. ${ }^{57}$ Genetically, engineered cacao plants constitutively expressing a chitinase gene showed decreased growth of Colletotrichum gleosporiodes and reduced symptoms of necrosis compared to the controls. ${ }^{58}$

Transgenic Citrus plants expressing an antimicrobial peptide under control of a double-enhanced $35 \mathrm{~S}$ promoter exhibited reduced symptoms of Citrus scab in greenhouse trials. ${ }^{59}$ Similar results were observed in transgenic strawberries expressing an antimicrobial protein. ${ }^{60}$ Transgenic grapevines expressing either antifungal or antibacterial genes under control of the $35 \mathrm{~S}$ promoter exhibited enhanced disease resistance and are currently in advanced stages of field testing. ${ }^{61}$ A number of PR proteins under the control of the $35 \mathrm{~S}$ promoter have also been employed to engineer disease resistance in ornamentals. Delayed symptoms of fungal diseases was observed in transgenic lines compared to the controls. $^{62}$ Transgenic roses constitutively expressing an antimicrobial peptide exhibited resistance to powdery mildew in greenhouse trials. $^{63}$ In other studies insect resistant transgenic fruits and vegetables have been produced by expressing a wide array of genes driven by the 35 S promoter. ${ }^{64-67}$

Transgenic horticultural crops with abiotic stress tolerance have been developed by constitutively expressing drought, cold and salinity-related genes. The Arabidopsis CBF transcription factors and its homologues from several species have been transferred to a number of fruit and vegetable crops for improving cold/chilling and drought tolerance. ${ }^{68-72} \mathrm{~A}$ number of antiporter and vacuolar genes have been utilized for enhancing salinity tolerance in several plant species. ${ }^{73-75}$

The $35 \mathrm{~S}$ promoter has been frequently used to downregulate genes involved in ethylene biosynthesis or fruit ripening and subsequently enhance shelf life and fruit quality. ${ }^{76-78}$ Transgenic tomatoes expressing antisense versions of genes responsible for fruit softening under control of a $35 \mathrm{~S}$ promoter exhibited enhanced shelf life due to their ability to inhibit or reduce fruit-specific enzymes responsible for softening of the fruit during the ripening process. ${ }^{79-81}$ Suppression of ripening-specific $\mathrm{N}$-glycoprotein modifying enzymes in tomato resulted in an increase in fruit shelf life without adversely affecting other qualitative characteristics. ${ }^{82}$

The $35 \mathrm{~S}$ promoter has also been used in a number of ornamental crops to modify plant structure, flower color and engineer floral scent in flowers that normally do not produce any fragrance. Enhanced anthocyanin production was observed in transgenic tobacco and petunia plants when a maize leaf color transcription factor was constitutively expressed by a $35 \mathrm{~S}$ promoter. ${ }^{83,84}$ Transgenic flower crops with unique colorations not generally observed in wild populations have been created by isolating genes from the pigment biosynthesis pathway and placing them under control of the $35 \mathrm{~S}$ promoter. ${ }^{85,86}$ Transgenic roses and carnations expressing unique colorations were also produced and released for commercial production. Transgenic petunia with reduced height and enhanced lateral branching were produced by constitutively expressing a zinc finger transcription factor. ${ }^{87}$ The enhanced branching patterns were attributed to alterations in cytokinin metabolism and increase in specific forms of cytokinins. Flowers with improved shelf life have also been produced by expressing various genes under the control of the $35 \mathrm{~S}$ promoter. ${ }^{88}$ Other efforts to improve traits in ornamental plants include the production of dwarf and compact plants and enhanced leaf color. ${ }^{89}$ Several attempts to introduce floral scent have been made using genetic engineering; such efforts have achieved partial success, mainly in part due to the absence of key enzymes or precursors that are required for the biosynthesis of the final biochemical compound..$^{90}$

Chimeric promoters that drive constitutive gene expression are created by combining elements from viral-derived sequences other than the 35S promoter. ${ }^{91,92}$ The Cassava vein mosaic virus (CVMV), figwort mosaic virus and Cestrum Yellow Leaf Curling Virus (CMPS) have been used to identify regulatory elements that would drive high levels of constitutive gene expression in plants. ${ }^{48,93-95}$ Such chimeric promoters created through shuffling of regulatory elements and inclusion of plant-derived or other viral-derived sequences have shown high levels of transgene expression in several plant species. In some cases, the activity of viral-derived constitutive promoters has been less effective in monocotyledonous species compared to dicotyledonous plant species. ${ }^{94}$ In other instances, viral-derived promoter sequences are known to direct high levels of gene expression in a wide array of dicot and monocot species. $^{96}$

Advances in genome sequencing of major crops of commercial importance and availability of high throughput sequence analyses have led to the isolation of several constitutive promoters from plant species. Promoters of constitutively expressed genes such as ubiquitin are ideal candidates due to their ability to drive high gene expression levels in transformed cells. Several grapevine promoters have been isolated from the sequenced genome and analyzed for their ability to direct gene expression in various plant tissues. ${ }^{97}$ Among the various candidates tested, ubiquitin promoters exhibited the highest activity levels when tested in grape somatic embryos and tobacco callus cultures, leaves and floral tissues. Two promoters Ubi-6-1 and Ubi7-2 exhibited gene expression levels comparable to a doubly enhanced $35 \mathrm{~S}$ promoter when fused to the gus and anthocyanin reporter genes. Higher levels of gene expression could be correlated with an increased number of ciselements in these promoters, which underlines the significance of identifying specific sequences in promoter regions for predicting expression levels. An ubiquitin extension promoter (uep 1) identified in oil palm exhibited constitutive expression in the native species as well as in tobacco, thereby indicating its utility in monocot and dicot groups of plants. ${ }^{98}$ A comparison of the activity of plantand viral-derived promoter sequences in transgenic Gladioulus found no differences in expression levels of GUS during the culture stage. ${ }^{99}$ However greenhouse-grown transgenic lines exhibited higher gene expression levels when the gus gene was driven by an Arabidopsis-derived rolD promoter. Transgenic chrysanthemums exhibited higher GUS expression levels when fused to a potato Lhca3.St. 1 promoter than the $35 \mathrm{~S}$ promoter. ${ }^{100}$ Such effects were attributed to potential post-transcriptional modifications leading to greater stability of the mRNA and higher expression levels.

\section{PROMOTERS INVOLVED IN FRUIT-SPECIFIC GENE EXPRESSION}

The ability of constitutive promoters to direct high levels of transgene expression can be a limiting factor when temporal and spatial gene expression patterns are required to achieve manipulation of specific plant organs or developmental stages. Constitutive expression of transcription factors by the $35 \mathrm{~S}$ promoter may interfere with normal plant development resulting in abnormal phenotypes. ${ }^{70,101}$ In other cases, the $35 \mathrm{~S}$ promoter may not be active in specific plant tissues thereby rendering it ineffective for directing high levels of spatial transgene expression. ${ }^{43}$ Tissue-specific promoters may be useful for directing transgenic expression in specific plant tissues without interfering with normal plant growth and development processes. A number of promoters involved in various stages of fruit growth, maturity and ripening have been identified and can be used as genetic engineering tools to improve fruit yield, quality and postharvest shelf life. Fruit-specific promoters with unique positive and negative regulatory elements may function efficiently in restricting 
tissue-specific expression of genes and avoiding the possibility of abnormal plant growth often observed with constitutive promoters. Fruit-specific promoters from both plant species that exhibit climacteric and non-climacteric ripening patterns have been studied.

A number of fruit-specific promoters are regulated by ethylene, which is involved in a number of developmental processes including fruit maturity, ripening and senescence. Promoters of ethylene responsive genes such as the $E 4$ and $E 8$ genes have been well studied to identify activator and suppressor elements that ensure spatial and temporal gene expression. ${ }^{102,103}$ Promoters from genes such as the ACC oxidase and ACO synthase isoforms that catalyze the key steps in ethylene biosynthesis have also been analyzed in a number of plant species to identify specific cis-elements involved in the regulatory process. ${ }^{104-106}$ Deletion analysis of a peach ACC oxidase promoter fused to the GUS gene revealed the presence of regulatory regions that controlled gene expression at specific stages of fruit ripening. ${ }^{107}$ Longer sequences of the promoter enhanced GUS expression in transgenic tomato, which was attributed to the presence of an enhancer element. Genes involved in tomato fruit development from the immature-green to maturegreen stages have been identified using large-scale microarray analysis to identify fruit-specific promoters that direct gene expression from ovary development to ripening. ${ }^{108}$ Analysis of a sour cherry expansin gene and its promoter region revealed the presence of a TATA box and several CAAT boxes that are conserved among promoter sequences. ${ }^{109}$ Additionally, sequences that were responsive to hormones (ethylene and gibberellins), an anaerobic responsive element, GATA boxes, pyrimidine box and other cis-elements that conferred tissue specificity were identified in the $5^{\prime}$ upstream region. Such sequences were highly conserved with previously identified cis-elements in other plant species. Promoter deletion analysis studies confirmed specific cis-elements that acted as positive regulators of gene expression in fruits at various stages of development. Similar results were obtained with the analysis of a cucumber fruit-specific expansion gene, CsExp. ${ }^{110}$ In addition to the TATA and CAAT boxes, light and hormone-responsive cis-elements with a high degree of homology with other similar elements in other species were identified. Genes responsible for sex expression in cucumber and expressed during fruit development were studied along with their promoter regions. ${ }^{111}$ Sequence analysis for two female-specific genes revealed gene duplication except for differences in the promoter regions. No differences were observed in the proximal promoter region of the CSACS1G and CSACS1 genes, which has cis-elements that acted as repressors of gibberellins. In silico analysis of the distal regions indicated the presence of auxinresponsive elements in the CsACS1G promoter, which could potentially confer responsiveness of this gene to specific hormonal factors and control female sex expression. ${ }^{111}$

The strawberry gene Faxy 1 coding for a fruit-specific $\beta$-xylosidase and potentially involved in hemicellulose degradation during fruit ripening was isolated along with its 5' flanking region. ${ }^{112}$ Analysis of the promoter region revealed the presence of several hormone, light and abiotic stress-related regulatory regions in addition to the TATA box and several CAAT boxes. While abscisic acid (ABA) treatment of peduncles enhanced gene expression and protein levels, a reduction was observed with $\mathrm{NAA}, \mathrm{GA}_{3}$ and ethylene treatment thereby indicating the presence of cis-elements that were positively and negatively regulated by specific hormones. Light responsive cis-elements such as ACE, SP1 G-box and MRE sequences were identified. The promoter region also included a number of cold, drought and heat-responsive elements.

A number of promoter sequences that are involved in the expression of genes involved in biochemical changes of fruit composition during development and ripening have been studied. ${ }^{13-115} \mathrm{~A}$ banana sucrose phosphate synthase (SPS) promoter that is involved in sucrose accumulation during ripening was analyzed to identify regulatory elements and their interaction with transcription factors. ${ }^{16}$
The presence of cis-elements regulated by light and hormonal interactions in addition to the TATA box and CAAT box indicated an interaction of plant hormones and environmental factors during the process of fruit ripening. In watermelon, the ADP-glucose pryophosphorylase gene, which is involved in carbohydrate metabolism during fruit ripening, was negatively regulated in the vegetative tissues. ${ }^{115}$ Removal of the cis-elements involved in negative regulation by fine promoter deletion analysis led to constitutive expression of the gene in leaf epidermal cells. Novel fruit-specific elements were identified in a cucumisin gene that is expressed in ripe melon fruits. ${ }^{114}$ Deletion analysis identified a fruit-specific enhancer element, and an I-box-like sequence, which negatively regulated cucumin biosynthesis in tissues other than the fruit. Similar elements with positive and negative regulatory functions were identified in a Citrus $\mathrm{C} 11$ promoter that was specifically expressed in juice sacs of ripening lemon fruit. ${ }^{117}$ Heterologous expression of the promoter: gus chimeric fusion in tomato revealed GUS expression specifically in the anthers and ovaries but not in vegetative tissues.

Promoters coding for metallothionin expression have been isolated from oil palm and Citrus. ${ }^{118,119}$ The oil palm promoter exhibited higher activity in the mesocarp tissue compared to leaf tissues. A core sequence that specified mesocarp expression while negatively regulating constitutive expression was identified in addition to specific enhancer elements that promoted expression in fruit tissues. Thus, tissue-specific expression appeared to be controlled by the combination of the positive and negative regulatory elements in the promoter region. ${ }^{119}$ Analysis of the Citrus methallothionin gene indicated the promoter to be in the TATA-less group of plant promoters such as those involved in photosynthesis. A number of fruit-specific cis-elements were identified in the promoter region and their function was confirmed by heterologous expression in Arabidopsis.

A number of genes for pigment production in fruits during the ripening phase have been well characterized. ${ }^{13,120-122}$ The $V v M y b A 1$ transcription factor is known to bind to specific regulatory elements of genes involved in the phenylalanine pathway, thereby promoting anthocyanin biosynthesis in grape berries post-veraison. A difference in the production of red and white colored berries in various grape cultivars is attributed to the insertion of a grape retrotransposon element GRET 1, which causes lack of pigment production resulting in white colored berries. ${ }^{123}$ Analysis of the grape dihydroflavonal reductase $(d f r)$ gene promoter region revealed the presence of regulatory elements that conferred expression in fruits during ripening. ${ }^{124} \mathrm{~A}$ transcription factor $L c M y b A 1$ that accumulated anthocyanin in litchi pericarp was found to be upregulated by light and ABA. ${ }^{125}$ Promoter analysis of the $L C M y b A 1$ gene revealed the presence of light, hormone and abiotic stress-responsive cis-elements that were involved in positive and negative regulation of gene expression. A Gentiana lutea carotenoid-related zeaxanthin epoxidase (GIZEP) gene and promoter region was analyzed for its function in carotenoid biosynthesis. ${ }^{126}$ Heterologous expression of a GIZEP:gus fusion in transgenic tomato specified carotenoid expression in flowers and ripe fruit but minimal levels in vegetative tissues, roots and immature fruit containing chloroplast. Cis-elements that are responsive to hormones and abiotic stress factors were identified in the promoter region and may be involved in carotenoid biosynthesis at specific developmental stages. In other studies, two fruit-specific promoters in tomato, SIACS4 and SIEXP1 contained regulatory elements that conferred gene expression specifically in seed, embryo and endosperm tissues. ${ }^{127}$ Candidate promoter sequences have also been identified from other fruits that exhibit seed-specific expression in heterologous species, indicating the presence of conserved cis-elements. ${ }^{128}$

Fruit-specific promoters have been used to either express or downregulate transgenic proteins at specific stages of development for enhancing fruit yield and quality. ${ }^{129-131}$ Transgenic tomatoes expressing miraculin, a taste modifying glycoprotein under control 
6

of an E8 promoter accumulated uniformly high levels of the transgenic protein in ripening fruits compared to fruits expressing the protein under a $35 \mathrm{~S}$ promoter, where protein accumulation occurred predominantly in the exocarp. ${ }^{132}$ Targeted expression of a yeast $S$-adenosylmethionine decarboxylase gene under the control of a fruit-specific E8 promoter significantly increased spermine and spermidine levels in transgenic tomato fruit, resulting in enhanced shelf life and higher lycopene content. ${ }^{133}$ Transgenic tomatoes expressing an Agrobacterium rolB gene under control of an ovary-specific promoter produced parthenocarpic fruit. ${ }^{134}$ No differences in fruit morphology were observed compared to the non-transformed fruit. In other studies, tomato fruits with enhanced rot resistance and shelf life were obtained by expressing a tomato anionic peroxidase under control of a fruit-specific E8 promoter. ${ }^{135}$ Transgenic avocado plants harboring a $S$-adenosine $L$-methionine hydrolyase gene under control of a fruit-specific cellulose promoter have been produced to study the potential for improving fruit shelf life. ${ }^{136}$ Targeted expression of a bacterial-derived auxin biosynthesis gene under control of a ovule-specific promoter significantly enhanced fecundity of transgenic 'Silcora' and 'Thompson Seedless' grapevines by improving berry and cluster size without compromising qualitative characteristics. ${ }^{137}$ Similar results of improved yield along with the production of parthenocarpic fruit were obtained in transgenic strawberry and raspberry plants. ${ }^{138}$

\section{PROMOTERS ACTIVE IN THE SEEDS}

The expression of genes that produce seed storage proteins is highly regulated. Deletion analysis of seed-specific promoters has led to identification of proximal regions that confer seed specificity and distal regions that are responsible for modulating gene expression. ${ }^{139-141}$ Many seed storage protein genes have been cloned from diverse plant species, and their promoters have been analyzed in detail to identify several cis- and trans-acting elements involved in gene regulation. ${ }^{139,140}$ Although such proteins exhibit wide structural variations, their promoters have a number of common properties. ${ }^{142}$ They allow the synthesis of proteins at high levels in specific tissues of the seed and at certain stages of plant development. ${ }^{143}$ The tightly regulated promoters make them ideal candidates for improving seed-specific traits such as nutritional value without potentially altering existing desirable characteristics. ${ }^{144}$

The $2 \mathrm{~S}$ albumin gene promoter from a number of horticultural species has been used to direct seed-specific gene expression. ${ }^{145-147}$ DNA sequence analysis of a seed-specific $2 S$ albumin promoter region derived from grape (Vitis vinifera L.) indicated that several conserved seed-specific regulatory motifs were clustered within a $0.6 \mathrm{~kb}$ region upstream of the transcription start site. A high level of GFP expression was observed in the cotyledonary but not hypocotyl and vegetative tissues of grape and tobacco indicating the ability of the promoter to direct seed-specific gene expression. ${ }^{145}$ This promoter region contained DNA motifs with core sequences identical to that of cotyledon box (CATGCA), F1 (ACGT) motif, F2 (CACCTC) motif, F3 (CACGTC) and AGGA box that have been previously characterized in $2 \mathrm{~S}$ albumin and related seed-specific promoters of other species ${ }^{147-149}$ Substitution mutation analysis of the napin promoter using promoter-reporter gene fusions in stable transgenic tobacco showed synergistic interactions between the Bbox and RY/G cis-elements within these complexes. It was further determined that elements in the B-box constitute an ABA-responsive complex and the seed-specific activity of the napA gene promoter relies on the combinatorial interaction between the RY/G complex and the $B$-box $A B A$-responsive complex during $A B A$ response in seed development. ${ }^{150}$ The $B$-box is highly conserved in all $2 S$ promoters and displays similarity to abscisic acid response elements. ${ }^{151}$

Legumin gene promoters have also been well studied in a number of plant species. In Pisum sativum, they are coded for by a multigene family. ${ }^{152}$ The promoter regions of $\operatorname{leg} A, \operatorname{leg} B$ and $\operatorname{leg} C$ were analyzed and were found to be identical including the TATA box and CAAT box. ${ }^{153}$ Deletion analysis of the pea legA major seed storage protein gene identified a minimal 549 bp upstream flanking sequence that was required for seed-specific expression. ${ }^{154}$ This fragment contained the leg box element, a 28 bp conserved sequence found in the legumin-type genes of Vicia, Pisum, Glycine and Helianthus. Larger promoter fragments significantly increased levels of seed-specific gene expression. ${ }^{143}$ DNA binding assays, however, indicated that the leg box element is not the sole promoter determinant in legumin gene expression since the $-124 \mathrm{bp}$ fragment which included the leg box did not bind to nuclear proteins. ${ }^{155}$ In addition, deletion of the leg box with its seed protein gene-specific CATGCATG motif has no obvious effects on expression levels. A $2.4 \mathrm{~kb}$ fragment containing the $5^{\prime}$-flanking region and the $5^{\prime}$-noncoding sequence of the Vicia faba legumin gene LeB4 was observed to mediate high level of seed-specific expression in transgenic tobacco plants. Deletion analysis revealed that a $1 \mathrm{~kb}$ of $5^{\prime}$-flanking sequence was sufficient for high-levels of expression. ${ }^{156}$ Similar to that observed with the pea legA promoter, positive regulatory, enhancer-like cis-elements are present within 566 bp of the upstream sequence. However, these elements are only fully functional in conjunction with the core motif CATGCATG of the legumin box present around position -95 . $^{157}$

Seed specificity within the 5 '-upstream region of a Vicia faba non-storage seed protein gene, called usp was mainly determined by the $-68 /+51$ region. Deletion analysis of the promoter revealed the $0.4 \mathrm{~kb}$ of usp upstream sequence contain at least six distinct interspersed cis-elements including an AT-rich sequence, a G-box element and a CATGCATG motif. ${ }^{158}$ The beta-phaseolin gene (phas), encoding the major seed storage protein of bean (Phaseolus vulgaris), is confined to the cotyledons of developing embryos. Promoter analysis revealed that although cis-elements extending 1470 bp upstream of the transcription start site can modulate gene expression, the proximal $295 \mathrm{bp}$ is sufficient to drive high levels of seed-specific GUS activity. ${ }^{141}$ The cis-regulatory CACGTG motif (G box) was identified as a major cis-acting regulatory element conferring spatial and temporal control of beta-phaseolin ${ }^{159}$ as substitution mutation of this motif reduced promoter activity by $75 \% .{ }^{160}$ In addition, there are three CANNTG motifs and two AG-1-binding sites in the beta-phaseolin promoter that play a critical role in gene transcription. ${ }^{160}$ Combinational interactions between multiple sequence motifs such as two upstream activating sequences UAS1 ( -295 to -109$)$ and UAS2 ( -468 to -391$)$ affected the spatial and temporal regulation of the promoter. While UAS1 was sufficient for seed-specific expression, UAS2 extended gene activity to the hypocotyl. Deletion of either of the two negative regulatory sequences, NRS1 ( -391 to -295$)$ and NRS2 $(-518$ to -418$)$, resulted in premature onset of GUS expression, indicating their role in the temporal control of gene expression. ${ }^{161}$

$D c 3$ is a carrot lea class gene expressed during embryogenesis in developing seeds and in vegetative tissues subject to drought and treatment with exogenous ABA. ${ }^{162}$ The proximal promoter region $(-117$ to +26$)$ is responsible for mediating the embryo-specific expression. ${ }^{163}$ The Dc3 promoter directed ABA and mannitol-inducible GUS expression in Arabidopsis guard cells and the two treatments were additive. ${ }^{164}$ A small family of bZIP transcription factors are involved in the seed-specific and ABA-responsive expression of the $D c 3$ gene. $D c 3$ binds to three DNA binding proteins, DPBF-1, 2 and 3. These DPBFs are bZIP factors that have been postulated to be global regulators of seed-specific and ABA-inducible genes. ${ }^{165}$ Deletion analysis of the promoter region led to the delineation of a proximal promoter region and a distal promoter region. The proximal promoter region contains cis-acting elements responsible for the developmental regulation of $D c 3$ expression in seeds. Both distal promoter region and proximal promoter region interact with common nuclear proteins that are present in embryos and 
inducible by $A B A$ in vegetative tissues. ${ }^{162}$ Following a 3-day water stress cycle, leaf GUS expression increased about 200-fold while there was a 16-fold increase in free ABA. These effects were reversed by re-watering indicating the drought inducibility of this promoter. In addition, $10 \mu \mathrm{M}$ ABA resulted in more than 10 -fold induction within $8 \mathrm{~h}^{166}$

Other cis-elements involved in seed-specific promoter expression such as a number of A/T-rich sequences and a CATGCAT/A sequence are present in the $5^{\prime}$-upstream regions of genes encoding concanavalin A (ConA) and canavalin, two major seed storage proteins of Canavalia gladiata, the sword bean. Deletion analysis of the promoter regions of both genes revealed positive regulatory elements located in the $-894 /-602$ and $-602 /-74$ regions of the Con $A$ gene, and in the $-428 /-376,-281 /-155$ and $-155 /-50$ regions of the canavalin gene. ${ }^{167}$

Progressive $5^{\prime}$ deletions of the pea lectin (Ps/) gene promoter identified a $22 \mathrm{bp}$ element (W1), important for seed-specific expression when coupled as a trimer to a heterologous TATA box. ${ }^{168}$ Within the 469 bp upstream region of the seed-specific pea lectin gene, a trimer of the $22 \mathrm{bp}$ fragment conferred high gene expression in seeds. This 22 bp fragment contains the binding site for the cloned basic domain/leucine zipper (bZIP) proteins TGA1a and Opaque-2 (O2), which in turn binds to the C-box ciselement (ATGAGTCAT) ${ }^{169}$ In a majority of the promoters, most of the cis-elements are located within $1 \mathrm{~kb}$ upstream of the ATG sequence. However, in the HaG3-A sunflower promoter that directs helianthinin gene expression, cis-regulatory elements located in a $2.4 \mathrm{~kb}$ upstream region were responsible for expression in a heterologous system. ${ }^{170}$ Similarly, the $2.4 \mathrm{~kb}$ in the $5^{\prime}$ upstream region of the CUMFT1 (citrus FT/TFL1 homolog from Satsuma mandarin (Citrus unshiu Marc.)) contained RY (CATGCAT), E-box (CANNTG) and distant B-box (GCCACTTGTC) cis-elements, all of which have been reported to promote seed-specific gene expression in plants. Seed-specific expression was confirmed by expressing the gus gene in Arabidopsis. ${ }^{171}$ A 0.8 kb fragment from the $5^{\prime}$-flanking region of a French bean beta-phaseolin gene yielded strong, temporally regulated and embryo-specific GUS expression in transgenic tobacco plants. ${ }^{140}$ Expression levels were observed to be similar as that obtained using the phaseolin seed protein promoter. ${ }^{172}$

Several promoters expressed in the seeds can also be expressed in other plant organs. The strictosidine synthase (Str) gene promoter from Catharanthus roseus contains a G-box sequence which helps to direct seed-specific expression independently of other regulatory sequences. G-box-directed expression in leaves, however, required the presence of an enhancer region from the $35 \mathrm{~S}$ promoter. ${ }^{173}$ The fruit and seed-specific expression of two tomato fruit-specific promoters SIACS4 and SIEXP1 was analyzed in transgenic tomato lines expressing the promoter: gus fusion constructs. The SIACS4 promoter $(-1$ to -373$)$ showed GUS activity restricted specifically to flower buds and seeds in fruits. On the contrary, the SIEXP1 promoter ( -1 to -769$)$ showed high level of expression in seeds as compared to fruit tissues at different stages of fruit ripening. ${ }^{127}$ The seed-specific expression shown by these promoters might be due to the presence of Prolamin box and E-boxes, which are conserved sequences found in the promoters of many seed storage proteins. ${ }^{150}$

\section{PROMOTERS ACTIVE IN THE FLORAL TISSUES}

In contrast to other plant organs, flowers are composite structures composed of several organs that form an ordered pattern. ${ }^{174}$ The typical flower consists of four organs arranged in whorls. The sepals consist of the outermost whorl followed by the petals in the next whorl and stamens (male reproductive organs) in the third whorl and carpels (female reproductive organs) in the innermost whorl. ${ }^{175}$ Each of these whorls consist of unique genes targeted to the specific organ and several homeotic genes that affect the fate of organ primordia. ${ }^{176}$ Targeted genetic engineering, by utilizing promoters obtained from genes specifically expressed in a specific whorl is highly desirable for targeted gene expression and can be exploited by using specific promoters. ${ }^{177}$ Some of the traits that can be engineered in the floral tissues include increased vase life, ${ }^{178-182}$ flower color modification, ${ }^{181,183-185}$ fragrance ${ }^{185-187}$ and male and female sterility ${ }^{188-192}$ among others.

Chalcone synthase (CHS) is synthesized in the flower corolla, tube and anthers ${ }^{193}$ and is important for the biosynthesis of flavonoid antimicrobial phytoalexins and anthocyanin pigments in plants. ${ }^{194}$ Various CHS promoters has been studied extensively in many plants, especially in Phaseolus vulgaris, antirrhinum, petunia and parsley. ${ }^{195-197}$ A 1.4 kb promoter fragment of the bean CHS8 gene was highly active in the root apical meristem and in petals and weakly expressed in other floral organs, mature leaves, and stems. ${ }^{198}$ Gene expression strongly depended on the G-box and H-box, ${ }^{199}$ as a synthetic 39 bp DNA fragment containing the two elements and linked to the minimal cauliflower mosaic virus $35 \mathrm{~S}$ promoter conferred a high level of tissue-specific expression. Mutations in either the G-box or H-box motifs abolished tissuespecific gene expression. ${ }^{195}$ A mutation in the G-box did not exhibit impaired promoter response to wounding, but demonstrated a $19 \%$ reduction in the response to $\mathrm{HgCl}_{2}$ and $\mathrm{TMV}$. A mutation at the $\mathrm{H}$-box resulted in a $30 \%$ increase in promoter response to wounding and reductions of $36 \%$ and $54 \%$ in the response to $\mathrm{HgCl}_{2}$ and $\mathrm{TMV}$, respectively, demonstrating the differential utilization of regulatory cis-elements. ${ }^{200} \mathrm{~A}$ silencer element present between positions -140 and -326 contained three binding sites for a bean nuclear factor (SBF-1). ${ }^{201}$ The region between -326 and -130 contained both activator and silencer elements. ${ }^{202}$ The petunia genome contains eight chalcone synthase genes, of which four are differentially expressed in floral tissues and UV light-induced seedlings. ${ }^{197}$ The chs promoter contains a 220 bp cis-acting element region conferring flower-specific and UV-inducible expression ${ }^{203}$ and its expression was enhanced when plant tissues were exposed to high carbohydrate levels. ${ }^{204}$ A promoter fragment from -67 to +1 , was able to direct low level flower-specific gene expression, but could not drive UV-inducible expression in transgenic Petunia seedlings. ${ }^{205}$ Histochemical analyses of GUS expression demonstrated that CHS promoters are not only active in pigmented cell types (epidermal cells of the flower corolla and tube and subepidermal cells of the flower stem), but also in a number of non-pigmented cell types (mesophylic cells of the corolla, several cell types in the ovary and the seed coat). ${ }^{197}$ The highest level of expression directed by the $1.1 \mathrm{~kb}$ snapdragon chalcone synthase promoter was observed in immature seeds. Deletions analysis identified regions of the promoter required for expression in roots, stems, leaves, seeds and flower petals of transgenic plants. A promoter fragment truncated to -39 activates transcription in roots of 4-week-old seedlings, whereas a fragment extending to $-197 \mathrm{bp}$ directed expression in petals and seeds. ${ }^{206,207}$ The positive regulatory element in the promoter consists of a $47 \mathrm{bp}$ direct repeat between positions -564 and $-670 .^{208} 150 \mathrm{bp}$ of the $5^{\prime}$ flanking region contained cis-acting signals for UV light-induced expression. $^{209}$ The GTCHS1 promoter from Gentiana triflora contains a sequence of the MYB protein-binding site, five consensus sequences of the MYC protein-binding site, one core sequence of a G-box and three P-box-like sequences. Gene expression is strongly directed flower limbs and the inner epidermis ${ }^{210}$ and is dependent on the G-box. ${ }^{211}$

In efforts to produce high transgene expression in petal tissue of ray florets of chrysanthemum, expression levels were compared with four petal-specific promoters: ubiquitin extension protein (UEP1) promoter from chrysanthemum chalcone synthase (chs- $A$ ) a zinc finger transcription factor (EPF2-5) from petunia, eceriferum (CER6) from Arabidopsis and multicystatin (PMC) from potato. The highest expression in petal tissue of ray and disc florets was 
conferred by the UEP1 promoter, followed by CER6 and EPF2-5. The UEP1 promoter in ray florets was reported to confer over 50 -fold enhancement in expression as compared to CaMV 35S-based promoters. $^{212}$

Promoters targeting other parts of the flower have also been evaluated. When a $2.4 \mathrm{~kb}$ fragment of the pistil-specific thaumatin/ PR5-like protein (PsTL1) promoter from Japanese pear (Pyrus serotina) was evaluated, ${ }^{213}$ it was observed that PSTL1 accumulated in pistils but not in other floral and vegetative organs which constitute a novel pistil-specific class of thaumatin/PR5-like protein. ${ }^{214,215}$ Other parts of the flower targeted include the flower receptacle. Promoters targeting other parts of the flower have been evaluated. When a $2.4 \mathrm{~kb}$ fragment of the pistil-specific thaumatin/PR5-like protein (PSTL1) promoter from Japanese pear (Pyrus serotina) was evaluated, ${ }^{213}$ it was observed that PsTL1 accumulated in pistils, but not in other floral and vegetative organs which constitute a novel pistil-specific class of thaumatin/PR5-like protein. ${ }^{214,215}$ Several reports exist on the isolation, characterization and use of promoters targeted to the flower receptacles, ${ }^{216,217}$ stamen, $^{218-220}$ anthers ${ }^{221-223}$ and ovaries. ${ }^{134}$ The potato SK2 gene promoter directed pistil-specific gene expression. It was observed that the regulatory elements responsible for pistilspecific expression were located within a 230 bp fragment. ${ }^{224}$

Numerous genes and their promoters that are expressed at the various stages during male gametogenesis have been cloned. ${ }^{225}$ Most of these have been isolated from agronomic crops such as maize ${ }^{226,227}$ rice $^{228,229}$ tobacco $^{230,231}$ and wheat ${ }^{232}$ as well as the model plant Arabidopsis. ${ }^{233-236}$ A few have also been isolated from horticultural crops. ${ }^{237}$ These promoters fused to a cytotoxic gene have been used to induce male sterility. ${ }^{226,238}$ The LAT52 and LAT59 anther-specific gene promoters from tomato have been evaluated in various crops for their anther-specific activity. ${ }^{237,239,240}$ These genes are very critical during tomato pollen development. In their absence, pollen germinates abnormally and is sterile. ${ }^{241}$ All major cis-regulatory elements required for pollen-specific transcription in the LAT52 promoter were located within -492 to $-52 .{ }^{242}$ Both promoters became active with the onset of microspore mitosis and increased progressively until anthesis, ${ }^{223}$ although the LAT52 promoter demonstrated a minor temporal difference in activity when tested in different plant species. ${ }^{243-245}$ The LAT52 promoter was highly active in electroporated pollen protoplasts isolated from Lilium longiflorum. $^{246}$ The antisense Bcp 1 gene under the control of the LAT52 promoter induced sterility in cauliflower pollen. ${ }^{247}$ Similarly, a $0.44 \mathrm{~kb}$ chiA PA2 promoter fragment from petunia drove pollen-specific gene expression and a $1.75 \mathrm{~kb}$ chiB PB promoter fragment conferred anther-specific (pollen and tapetum cells) expression to the gus gene. ${ }^{222}$ The TomA108 gene promoter from tomato was also highly active from early-meiosis to free microspores production in the tapetum. ${ }^{248}$ Deletion analysis of the BAN215-6 gene promoter isolated from the Chinese cabbage identified a $383 \mathrm{bp}(-274-+109)$ region that was observed to be sufficient for the anther-specific expression of the gus gene. GUS expression was first detected in uninucleate microspores, increased during anther development and reached its highest level in mature pollens. ${ }^{249}$ Similar observation were made with the $2.7 \mathrm{~kb}$ promoter fragment of a pea END1 gene. This promoter was evaluated in several species and observed to be fully functional in the anthers. ${ }^{250}$

\section{PROMOTERS ACTIVE IN THE ROOT SYSTEM}

Plant roots have been essential for the evolution of vascular plants enabling them to meet the requirements for anchorage and the acquisition of water and nutrients. ${ }^{251}$ Roots are multifunctional and involved in the acquisition of water and nutrients, anchorage of the plant and storage functions. ${ }^{252,253}$ In fact, plant productivity is dependent on a heathy root system ${ }^{254}$ as problem with root health directly affects the above ground part. ${ }^{255,256}$ Roots interact with its surrounding environment ${ }^{257}$ and can be susceptible to a multitude of problems stemming from the environment in which it lives. ${ }^{252,258-260}$ Targeted gene expression by using root-specific promoters can allow for the development of horticultural plants better suited for growth in a range of soil types, soil $\mathrm{pH}$ and under microbial stress. ${ }^{261,262}$ Several root-specific promoters have been evaluated in horticultural plants. The SLREO gene isolated from tomato is highly expressed in roots, but had a very low level of expression in aerial plant organs. ${ }^{263}$ The RB7 protein from tobacco, ${ }^{262}$ is a membrane channel aquaporin, allowing the diffusion of amino acids and/or peptides from the vacuolar compartment to the cytoplasm. ${ }^{264,265}$ This promoter is root-specific and has been used to drive the Arabidopsis thionin (Thi2.1) gene in tomato. ${ }^{266}$ A strawberry homolog (FaRB7) behaves in the same way as the tobacco RB7 promoter. ${ }^{267}$ Other promoters identified include a $2 \mathrm{~kb}$ promoter fragment of the MipB gene from Mesembryanthemum crystallinum that was observed to be expressed strongly in the tobacco root. However, gene expression was also observed in other rapidly expanding cells and cells with high water flux capacity. ${ }^{268}$

Several root nodule-specific promoters have been identified from leguminous plants. ${ }^{269}$ A $1.3 \mathrm{~kb}$ fragment of the French bean $\mathrm{gln}$ gamma gene promoter is strongly induced during nodule development. $^{270}$ The Vicia faba VfLb29 gene promoter was found to be specifically active not only in the infected cells of the nitrogen-fixing zone of root nodules but also in arbuscule-containing cells of transgenic $V$. faba roots colonized by the endomycorrhizal fungus Glomus intraradices. ${ }^{271}$ A promoter fragment (-692/41) encoding the Vicia faba early nodulin VfEnod 12 and containing a putative binding site for the transcription factor ENBP1, mediated reporter gene expression in root cortical cells, nodule primordia and the prefixing zone II of transgenic Vicia hirsute root nodules. ${ }^{272}$ A $1.9 \mathrm{~kb}$ fragment of the Sesbania rostrata leghemoglobin glb3 $5^{\prime}$-upstream region was found to direct a high level of nodule-specific GUS activity in lotus. Replacement of the -161 to -48 region, containing the glb3 CAAT and TATA boxes, with the heterologous truncated promoters delta-p35S and delta-pnos, resulted in a loss of nodule specificity and reduction of GUS activity restricted to the Rhizobium-infected cells of the nodules. ${ }^{273}$ Promoter analyses of pea PSENOD12A and PsENOD12B, nodulin gene promoters showed that the $200 \mathrm{bp}$ immediately upstream of the transcription start are sufficient to direct nodule-specific and Nod factor-induced gene expression. ${ }^{274}$ GUS activity was only detected in the infected cells of the nodules of lotus transgenic plants when a Npv30 promoter isolated from Phaseolus vulgaris fused to the gus reporter gene was used. ${ }^{275}$

Several genes are highly upregulated in tubers. ${ }^{276-278}$ Many of these storage gene promoters have been exploited for horticultural crop improvement. Patatin is a major tuber protein and is very tissue-specific. ${ }^{279}$ The $1.5 \mathrm{~kb} 5^{\prime}$-upstream region of the class I patatin gene $B 33$ directed strong expression of the GUS reporter gene in potato tubers which was on average 100- to 1000 -fold higher in tubers as compared to leaf, stem and roots. ${ }^{280}$ Gene expression was also induced by sucrose application. ${ }^{278}$ Deletion analysis identified a tuber-specific element located downstream from position -195 . Sequences between -40 and $-400 \mathrm{bp}$ and between -400 and $-957 \mathrm{bp}$ of the transcriptional start site were able to confer tuber-specific expression on a heterologous truncated promoter. ${ }^{281}$ Sucrose inducibility was controlled by sequences downstream of position $-228 .{ }^{282,283}$ High levels of mature human serum albumin was expressed in potato tubers using the potato patatin B33 tuberspecific promoter. ${ }^{284}$

Sporamin accounts for more than $80 \%$ of the total soluble proteins of tuberous roots of sweet potato ${ }^{285}$ and can be induced by wounding and sucrose. ${ }^{286}$ Two wound response-like elements, a G box-like element and a GCC core-like sequence, were found in the sporamin gene promoter. ${ }^{287}$ When overexpressed in potato, the sporamin promoter was highly active in leaves, stems and different size tubers. ${ }^{288}$ Deletion of the sporamin A promoter sequences extending from position -305 (relative to the transcription start 
site) to -283 and from -146 to -87 resulted in an approximately 40 -fold enhancement in GUS reporter expression. It was observed that the sequence between positions -282 and -165 contained to two cis-acting elements, termed CMSREs (carbohydrate metabolite signal responsive elements) 1 and 2 are responsible for the sucroseresponsiveness of the promoter. ${ }^{289}$

\section{PROMOTERS ACTIVE IN THE VASCULAR TISSUES}

The plant's vascular system acts as a bridge between the leaves and other parts of the shoot, with the roots. ${ }^{290}$ This system, comprised of two kinds of conducting tissue, the xylem and phloem enables efficient long-distance transport between the organs. ${ }^{291}$ Xylem is primarily responsible for water transport and movement of soluble mineral nutrients from the roots throughout the plant. ${ }^{292}$ Phloem, on the other hand, transports sugars from source tissues such as the photosynthetic leaf cells to sink or storage tissues such as the roots, flowers or fruits. ${ }^{293,294}$ Targeting a transgene into the vasculature using either a xylem or phloem-specific promoter allows gene expression at the site of infection and can potentially control vascular maladies. It can also provide a rapid response in response to wounding and for the control of aphids and other sap sucking insects. ${ }^{295-297}$

A 494 bp promoter fragment of the glycine-rich wall protein GRP 1.8 from the French bean translationally fused to the gus gene expressed the gene in vascular tissue of roots, stems, leaves and flowers. Four cis-acting regulatory regions, SE1 and SE2 (stem elements), a negative regulatory element and a root-specific element, were found to control the tissue-specific expression. ${ }^{298}$ The vs-1 motif in the GRP 1.8 promoter was a cis-element that specifically bound to a transcription activation factor VSF-1 protein and allows xylem-specific expression. ${ }^{299}$ The gene was developmentally expressed during differentiation of both primary and secondary vascular tissue and was also rapidly induced (within $<30 \mathrm{~min}$ ) after excision-wounding of young stems. ${ }^{300}$ The bean phenylalanine ammonia-lyase gene 2 (PAL2) is expressed in the early stages of vascular development at the inception of xylem differentiation. Deletion analysis revealed the presence of cis-elements located between nucleotides -289 and -74 relative to the transcription start site being essential for xylem expression. ${ }^{301}$ Expression of the PAL2 promoter in the vascular system involves positive and negative regulatory cis-elements. Among these elements is an AC-rich motif implicated in xylem expression. ${ }^{302}$ Similarly, the citrus PAL gene (CSPP) promoter fused to the gus gene and transformed into tobacco and 'Valencia' sweet orange preferentially, but not exclusively, conferred gene expression in xylem tissues of tobacco. Weaker GUS staining was also detected throughout the petiole region in tobacco and citrus CSPP transgenic plants. ${ }^{303}$ The Arabidopsis PAL promoter when transformed into citrus expressed exclusively in the xylem parenchyma. ${ }^{304}$

The full-length promoter and a series of $5^{\prime}$ deletions of the pea cytosolic glutamine synthetase GS3A gene were fused to the gus gene and introduced into tobacco and alfalfa. The GS3A promoter directed GUS expression in the phloem cells of the vasculature in leaves, stems and roots. Interestingly, the promoter was found to be active even when deleted to -132 relative to the start of transcription. ${ }^{305}$ The Arabidopsis sucrose- $\mathrm{H}^{+}$symporter AtSUC2 ${ }^{306}$ has been used to direct phloem-specific gene expression in a number of horticultural crops, such as Mexican lime, ${ }^{307}$ sweet orange, pears $^{309}$ and strawberries. ${ }^{310}$ Two alleles of the Citrus sinensis sucrose synthase-1 promoter (CSSUS1p) were inserted upstream of the gus gene to test their ability to drive expression in the phloem of transgenic $A$. thaliana and $N$. tabacum. Although both promoter variants were capable of conferring localized GUS expression in the phloem, the CSSUS1p-2 allele also generated a significant level of expression in non-target tissues. Deletion analysis of the CsSUS1p suggested that a fragment comprising nucleotides
-410 to -268 relative to the transcriptional start site contained elements required for phloem-specific expression, while nucleotides -268 to -103 contained elements necessary for wound-specific expression. ${ }^{311}$ In citrus, the CSSUS promoter appeared leaky with some laminar tissue staining. ${ }^{312}$ A citrus phloem protein 2 (CsPP2) promoter was also evaluated in sweet orange and gene was observed to be preferentially expressed in the phloem. ${ }^{308}$ Two heterologous promoters, rolC and CoYMVP, were fused with the gus reporter gene and evaluated in the vegetative tissues of apple. It was observed that the CoYMV promoter was slightly more active than the rolC promoter, although both expressed GUS at a lower level than the CaMV $35 \mathrm{~S}$ promoter. This analysis demonstrated that with both the rolC and CoYMV promoters the reporter gene activity was primarily localized to vascular tissues, particularly the phloem. ${ }^{313}$

\section{INDUCIBLE PROMOTERS}

These promoters are induced by either physical factors such as biotic and abiotic factors or chemical agents and is a powerful tool to regulate the expression of genes at certain stages of plant or tissue development. ${ }^{314-318}$ Examples of physically regulated promoters include heat shock promoters, ${ }^{319}$ cold inducible promoters, ${ }^{320}$ light inducible promoters, ${ }^{321}$ light repressible promoters ${ }^{322}$ or wound inducible promoters. ${ }^{323}$ Chemically inducible promoters include alcohol regulated promoters, ${ }^{324}$ tetracycline regulated promoters, ${ }^{325}$ steroid responsive promoters such as glucocorticoid receptor promoters, estrogen and ecdysone receptor promoters, ${ }^{316,326}$ metal-responsive promoters ${ }^{327}$ and pathogenesis related promoters. ${ }^{328}$ Some of these promoters have been isolated from horticultural crops or used for horticultural plant improvement.

The potato proteinase inhibitor II gene (pinll) is a chymotrypsin and trypsin inhibitor ${ }^{329}$ and is wound and UV irradiation inducible. ${ }^{330,331}$ The sequence TATAAA is found 26 nucleotides upstream of the transcription initiation site and the sequence CAAAT at position -103 in the promoter. ${ }^{332}$ The wound inducibility of this promoter has been evaluated in several plant species to test gene function that involve cell-specific and systemic induction. ${ }^{333}$ The Pinll promoter has been utilized in the wound-inducible expression of the bacterial isopentenyl transferase (ipt) gene into Nicotiana plumbaginifolia. $^{334}$ In transgenic rice plants, the expression of the pinll-gus fusion gene displayed a systemic wound response. ${ }^{335}$ In alfalfa, GUS expression was observed in leaf and root vascular tissue, and in some plants, expression was observed in leaf mesophyll cells. Mechanical wounding of leaves increased GUS expression approximately twofold over $24 \mathrm{~h}^{336}$ The Pinll promoter is active in monocot species also. Localized induced gene expression was obtained in white spruce seedlings (Picea glauca) using a similar pinll-gus construct. $^{337}$ In rice, the wound-inducible expression of the pinll gene driven by its own promoter, together with the first intron of the rice actin 1 gene (act 1), resulted in high-level accumulation of the PINII protein in the transgenic plants. ${ }^{338}$ The wun1 gene is another wound inducible gene from potato. ${ }^{339}$ Histochemical analysis of transgenic tobacco plants that expressing the wun1-gus fusions demonstrated the wound-inducible and cell-specific wun 1 promoter activity in plants containing the -1022 bp fragment. ${ }^{340}$

The tomato Lehsp23.8 heat shock protein gene's expression is induced by treatment with high or low temperatures, heavy metal or ABA. Using the gus reporter gene system, the developmental and tissue-specific expression of the gus gene controlled by the Lehsp23.8 promoter was characterized in transgenic tomato plants. The optimal heat-shock temperatures leading to the maximal GUS activity in the pericarp of green, breaker, pink and red fruits were 42, 36,39 and $39{ }^{\circ} \mathrm{C}$, respectively. ${ }^{341}$ Deletion analysis of the Lehsp23.8 promoter revealed a proximal region $(-565$ to $-23 \mathrm{bp})$ to harbor cis-regulatory elements that conferred high levels of heat-induced expression in transgenic tobacco. Mutation of the five proximal 
HSEs (HSE1 to 5) led to an absence of heat inducibility. ${ }^{342}$ The tomato chloroplast small heat shock protein (HSP), HSP21, is also induced by heat treatment in leaves. ${ }^{343}$ Several sunflower genes encode small HSPs. ${ }^{344,345}$ In vegetative tissues, these mRNAs accumulated in response to either heat shock $\left(42{ }^{\circ} \mathrm{C}\right), \mathrm{ABA}$ or mild water stress treatments. The Hahsp17.7G4 mRNA is also active during zygotic embryogenesis at $25^{\circ} \mathrm{C}$. Developmental induction of the G4 promoter was faithfully reproduced during zygotic embryogenesis in transgenic plants containing G4: GUS translational fusions. Distal sequences of this promoter (between -1132 and -395) were needed to confer a preferential spatial expression of GUS activity in the cotyledons while proximal regions confer responses to $A B A$ and heat shock ${ }^{346}$ This -83 to +163 fragment was observed to be sufficient to support a promoter activity in tobacco galls induced by the root-knot nematode Meloidogyne incognita. GUS activity was largely restricted to giant cells within the galls. ${ }^{347}$ However, the Hahsp17.6G1 (G1) promoter which is not induced by heat shock, was observed to be silent in these giant cells, indicating that the high metabolic rate of giant cells produced as a result of nematode infection may somehow mimic heat-shock and/or other stress responses. ${ }^{348}$ Other examples include the strong oxidative stress-inducible peroxidase SWPA2 promoter from sweet potato. This promoter contained several cis-element sequences implicated in oxidative stress such as GCN-4, AP-1, HSTF and SP-1 reported in animal cells and a plant-specific G-box. A 1314 bp promoter fragment fused to the gus gene and transformed into tobacco exhibited about 30 times higher GUS expression than the CaMV 35S promoter in response to environmental stresses including hydrogen peroxide, wounding and UV treatment. ${ }^{349}$ similarly, when potatoes were transformed with a stress inducible Arabidopsis rd29A promoter driving the cold tolerance CBF genes, freezing tolerance was increased by $2{ }^{\circ} \mathrm{C}$. 350

Several promoters are chemically induced. Ethylene treatment or leaves wounding rapidly induced the melon ACC oxidase gene, CMACO1-gus gene in transgenic tobacco plants. ${ }^{351}$ Jasmonates and alpha-linolenic acid strongly induced the expression of the wound-induced $4 \mathrm{CL}$ promoter in parsley cell cultures and transgenic tobacco plants expressing 4CL1-GUS gene fusions. This supported a role for jasmonates in mediating wound-induced gene expression. ${ }^{352}$ Two wound response-like elements, a G box-like element and a GCC core-like sequence were found within a $1.25 \mathrm{~kb}$ sporamin promoter. Transgenic tobacco containing this promoter driving the gus gene was wounded and a high level of GUS activity was observed in stems and leaves of, but not in roots. Exogenous application of methyl jasmonate also activated the sporamin promoter in leaves and stems of sweet potato. ${ }^{287}$ The chemically inducible PR-1a tobacco promoter was fused to the Bacillus thuringiensis cry $1 A b$ gene and transformed into broccoli. Two progeny lines expressed the $c r y 1 A b$ gene and provided insect resistance when treated with the chemical inducers 2,6-dichloroisonicotinic acid or 1,2,3-benzothiadiazole-7-carbothioic acid S-methyl ester. ${ }^{353}$ Other examples include the alfalfa pathogen-inducible PR 10 promoter. This promoter fused to the Vitis stilbene synthase 1 ( VvSS1) gene was introduced into the grape rootstock genome. Transgenic plants accumulated 5- to 100-fold resveratrol in leaves infected with Botrytis using an in vitro test. ${ }^{354}$

Some promoters can be regulated both physically and chemically. A $2.2 \mathrm{~kb}$ promoter region of the tomato prosystemin gene fused to the gus gene and transformed back into tomato contains elements conferring its correct temporal and spatial expression in the vascular bundles of transgenic tomato plants by wounding and by treatment of the plants with methyl jasmonate. ${ }^{323}$

\section{CONCLUSIONS}

The global human population is increasing at an unprecedented rate and is projected to cross 11 billion before the end of this century. ${ }^{355}$ This doubling of the population and a rapid increase in global food demand creates huge challenges for the sustainability both of food production and the ability to grow more from a shrinking cultivable land mass. Thus far, the combined effects of improved varieties, increased fertilizer use and irrigation coupled with increased pesticide use have been instrumental in allowing world food production to double in the last 35 years ${ }^{356} \mathrm{~A}$ multifaceted and linked global strategy to increase food production from shrinking land and water resources will ensure sustainable and equitable food security. ${ }^{357,358}$ Fruits and vegetables claimed an increasing share of the world agricultural trade, from $10.6 \%$ in 1961 to $17 \%$ in $2001 .{ }^{359}$ It is expected that demand for horticultural commodities, especially fruits, vegetables and flowers will continue to increase with the increase in the purchasing ability of the expanding middle class and an growing awareness of the many health benefits associated with an increased consumption of fruits and vegetables. ${ }^{360,361}$

Acreage under genetically modified crop plants has increased substantially in recent years as more and more acreage is consumed to feed, clothe and sustain a growing world population. ${ }^{362}$ However, there has been limited progress in the commercialization of genetically modified horticultural commodities, with the exception of the Hawaiian papaya cultivars resistant to papaya ringspot virus 363,364 and color-altered varieties of carnation flowers. ${ }^{365}$ Development of genetically modified horticultural cultivars that can alleviate consumer concerns and the related reluctance of food processors and marketers to accept new biotech horticultural commodities can speed up the introduction of horticultural products already developed. ${ }^{366}$

In recent years, molecular advancement in the field of bioinformatics has been rapid. ${ }^{37}$ With the genome of a number of horticultural species being sequenced and the availability of numerous online databases for analyzing, identifying and characterizing promoters from different horticultural species, ${ }^{367-371}$ it has become relatively easier to identify and characterize plant derived promoters and other genetic elements. Identification and incorporation of plant promoter and other genetic sequences by exploiting the expanding public databases and bioinformatics services can potentially alleviate some of the public concerns about safety issues with the use of a genetically modified horticultural crop. ${ }^{372,373}$ Development of precision breeding techniques (previously termed as cisgenic or intragenic genetic improvement) ${ }^{374}$ will enable more precise genetic modification of plants. ${ }^{375}$ The resulting horticultural plant, devoid of DNA from other gene pool and restricted to a modulation of existing traits from the sexually compatible gene pool, could also result in less comprehensive regulation towards the release of a precision bred plant, thereby decreasing the regulatory approval costs. 373

\section{COMPETING INTERESTS}

The authors declare no conflict of interest.

\section{REFERENCES}

1 Mitsuhara, I, Ugaki M, Hirochika $\mathrm{H}$ et al. Efficient promoter cassettes for enhanced expression of foreign genes in dicotyledonous and monocotyledonous plants. Plant Cell Physiol 1996; 37: 49-59.

2 Komarnytsky S, Borisjuk N. Functional analysis of promoter elements in plants. In: Setlow J (ed.) Genetic Engineering. Vol. 25. Berlin: Springer, 2003: 113-141.

3 Lee TI, Young RA. Transcription of eukaryotic protein-coding genes. Annu Rev Genet 2000; 34: 77-137.

4 Katagiri F, Chua NH. Plant transcription factors: present knowledge and future challenges. Trends Genet TIG 1992; 8: 22-27.

5 Banerji J, Rusconi S, Schaffner W. Expression of a beta-globin gene is enhanced by remote SV40 DNA sequences. Cell 1981; 27: 299-308.

6 Singh KB. Transcriptional regulation in plants: the importance of combinatorial control. Plant Physiol 1998; 118: 1111-1120.

7 Wu K, Malik K, Tian L et al. Enhancers and core promoter elements are essential for the activity of a cryptic gene activation sequence from tobacco, tCUP. Mol Genet Genomics 2001; 265: 763-770. 
8 Novina CD, Roy AL. Core promoters and transcriptional control. Trends Genet 1996 12: $351-355$.

9 Juven-Gershon T, Kadonaga JT. Regulation of gene expression via the core promoter and the basal transcriptional machinery. Dev Biol 2010; 339: 225-229.

10 Smale ST, Baltimore D. The "initiator" as a transcription control element. Cell 1989; 57: 103-113.

11 Breathnach R, Chambon P. Organization and expression of eucaryotic split genes coding for proteins. Annu Rev Biochem 1981; 50: 349-383.

12 Means AL, Farnham PJ. Transcription initiation from the dihydrofolate reductase promoter is positioned by HIP1 binding at the initiation site. Mol Cell Biol 1990; 10 653-661.

13 Mukherjee B, Burma S, Hasnain SE. The 30-kDa protein binding to the "initiator" of the baculovirus polyhedrin promoter also binds specifically to the coding strand. J Biol Chem 1995; 270: 4405-4411.

14 Seto E, Shi Y, Shenk T. YY1 is an initiator sequence-binding protein that directs and activates transcription in vitro. Nature 1991; 354: 241-245.

15 Smale ST, Baltimore D. The "initiator" as a transcription control element. Cell 1989; 57: 103-113.

16 Zenzie-Gregory B, O'Shea-Greenfield A, Smale ST. Similar mechanisms for transcription initiation mediated through a TATA box or an initiator element. J Biol Chem 1992; 267: 2823-2830.

17 Gudynaite-Savitch L, Johnson DA, Miki BL. Strategies to mitigate transgenepromoter interactions. Plant Biotechnol J 2009; 7: 472-485.

18 Wen Z, Yang YZ, Zhang JJ et al. Highly interactive nature of flower-specific enhancers and promoters, and its potential impact on tissue-specific expression and engineering of multiple genes or agronomic traits. Plant Biotechnol J 2014; in press.

19 Koltunow AM, Truettner J, Cox KH, Wallroth M, Goldberg RB. Different temporal and spatial gene expression patterns occur during anther development. Plant Cell 1990; 2: 1201-1224.

20 Yang Y, Li R, Qi M. In vivo analysis of plant promoters and transcription factors by agroinfiltration of tobacco leaves. Plant J 2000; 22: 543-551.

21 Hartmann U, Sagasser M, Mehrtens F, Stracke R, Weisshaar B. Differential combinatorial interactions of cis-acting elements recognized by R2R3-MYB, $B Z I P$, and BHLH factors control light-responsive and tissue-specific activation of phenylpropanoid biosynthesis genes. Plant Mol Biol 2005; 57: 155-171.

22 Maniatis T, Goodbourn S, Fischer JA. Regulation of inducible and tissue-specific gene expression. Science 1987; 236: 1237-1245.

23 Krieger EK, Allen E, Gilbertson LA, Roberts JK. The Flavr Savr tomato, an early example of RNAi technology. HortScience 2008; 43: 962-964.

24 Martineau B. First Fruit: The Creation of the Flavr Savr Tomato and the Birth of Biotech Foods. New York: McGraw-Hill Companies, 2001.

25 Kramer, MG, Redenbaugh K. Commercialization of a tomato with an antisense polygalacturonase gene: the FLAVR SAVR ${ }^{T M}$ tomato story. Euphytica 1994; 79: 293-297.

26 Odell JT, Nagy F, Chua NH. Identification of DNA sequences required for activity of the cauliflower mosaic virus 35 S promoter. Nature 1985; 313: 810-812.

27 Benfey PN, Chua NH. The cauliflower mosaic virus 35S promoter: combinatorial regulation of transcription in plants. Science 1990; 250: 959-966.

28 Opperman CH, Taylor CG, Conkling MA. Root-knot nematode-directed expression of a plant root-specific gene. Science 1994; 263: 221-223.

29 Ruf S, Hermann M, Berger IJ, Carrer H, Bock R. Stable genetic transformation of tomato plastids and expression of a foreign protein in fruit. Nat Biotechnol 2001; 19: $870-875$

30 Kizis $D$, Lumbreras $V$, Pagès $M$. Role of AP2/EREBP transcription factors in gene regulation during abiotic stress. FEBS Lett 2001; 498: 187-189.

31 Yamamoto YY, Obokata J. ppdb: a plant promoter database. Nucleic Acids Res 2008; 36: D977-D981.

32 Rombauts $S$, Déhais $P$, van Montagu $M$, Rouzé $P$. PlantCARE, a plant cis-acting regulatory element database. Nucleic Acids Res 1999; 27: 295-296.

33 Lescot $M$, Déhais $P$, Thijs $G$ et al. PlantCARE, a database of plant cis-acting regulatory elements and a portal to tools for in silico analysis of promoter sequences. Nucleic Acids Res 2002; 30: 325-327.

34 Goodman RM, Hauptli H, Crossway A, Knauf VC. Gene transfer in crop improvement. Science 1987; 236: 48-54.

35 Birch RG. Plant transformation: problems and strategies for practical application. Annu Rev Plant Biol 1997; 48: 297-326.

36 Gupta P, Raghuvanshi S, Tyagi AK. Assessment of the efficiency of various gene promoters via biolistics in leaf and regenerating seed callus of millets, Eleusine coracana and Echinochloa crusgalli. Plant Biotechnol 2001; 18: 275-282.

37 Porto MS, Pinheiro MP, Batista VG et al. Plant promoters: an approach of structure and function. Mol Biotechnol 2014; 56: 38-49.

38 Kay R, Chan A, Daly M, McPherson J. Duplication of CaMV 35 S promoter sequences creates a strong enhancer for plant genes. Science 1987; 236: 1299-1302.
39 Schnurr J, Guerra D. The CaMV-35S promoter is sensitive to shortened photoperiod in transgenic tobacco. Plant Cell Rep 2000; 19: 279-282.

40 Pretová A, Obert B, Wetzstein $\mathrm{H}$. Leaf developmental stage and tissue location affect the detection of $\beta$-glucuronidase in transgenic tobacco plants. Biotechnol Lett 2001; 23: 555-558.

41 de Mesa MC, Santiago-Doménech N, Pliego-Alfaro F, Quesada M, Mercado J. The CaMV $35 \mathrm{~S}$ promoter is highly active on floral organs and pollen of transgenic strawberry plants. Plant Cell Rep 2004; 23: 32-38.

42 Mascarenhas JP, Hamilton DA. Artifacts in the localization of GUS activity in anothers of petunia transformed with a CaMV 35S-GUS construct. Plant J 1992; 2: $405-408$.

43 van der Leede-Plegt LM, van de Ven BC, Bino RJ, van der Salm TP, van Tunen AJ. Introduction and differential use of various promoters in pollen grains of Nicotiana glutinosa and Lilium longiflorum. Plant Cell Rep 1992; 11: 20-24.

44 de Jong J, Mertens MM, Rademaker W. Stable expression of the GUS reporter gene in chrysanthemum depends on binary plasmid T-DNA. Plant Cell Rep 1994; 14: 59-64.

45 Bhullar S, Datta S, Advani S et al. Functional analysis of cauliflower mosaic virus 35S promoter: re-evaluation of the role of subdomains B5, B4 and B2 in promoter activity. Plant Biotechnol J 2007; 5: 696-708.

46 Mitsuhara I, Ugaki M, Hirochika $\mathrm{H}$ et al. Efficient promoter cassettes for enhanced expression of foregin genes in dicotyledonous and monocotyledonous plants. Plant Cell Physiol 1996; 37: 49-59.

47 Dhadi SR, Krom N, Ramakrishna W. Genome-wide comparative analysis of putative bidirectional promoters from rice, Arabidopsis and Populus. Gene 2009; 429: 65-73.

48 Li ZT, Jayasankar S, Gray D. Bi-directional duplex promoters with duplicated enhancers significantly increase transgene expression in grape and tobacco. Transgenic Res 2004; 13: 143-154.

49 Li ZT, Kim KH, Jasinski JR, Creech MR, Gray DJ. Large-scale characterization of promoters from grapevine (Vitis spp.) using quantitative anthocyanin and GUS assay systems. Plant Sci 2012; 196: 132-142.

50 Fitch MM, Manshardt RM, Gonsalves D, Slightom JL, Sanford JC. Stable transformation of papaya via microprojectile bombardment. Plant Cell Rep 1990; 9: 189-194.

51 Gonsalves D, Gonsalves C, Ferreira S et al. Transgenic virus resistant papaya: From hope to reality for controlling papaya ringspot virus in Hawaii. APSnet Feature, July 2004.

52 Scorza R, Ravelonandro M, Callahan AM et al. Transgenic plums (Prunus domestica L.) express the plum pox virus coat protein gene. Plant Cell Rep 1994; 14: 18-22.

53 Scorza R, Callahan A, Levy L, Damsteegt V, Webb K, Ravelonandro M. Posttranscriptional gene silencing in plum pox virus resistant transgenic European plum containing the plum pox potyvirus coat protein gene. Transgenic Res 2001; 10: 201-209.

54 Scorza R, Callahan A, Dardick C et al. Genetic engineering of Plum pox virus resistance: 'HoneySweet' plum-from concept to product. Plant Cell Tissue Organ Culture (PCTOC) 2013; 115: 1-12.

55 Zanek MC, Reyes CA, Cervera M et al. Genetic transformation of sweet orange with the coat protein gene of Citrus psorosis virus and evaluation of resistance against the virus. Plant Cell Rep 2008; 27: 57-66.

56 Fuentes A, Ramos PL, Fiallo E et al. Intron-hairpin RNA derived from replication associated protein $\mathrm{C} 1$ gene confers immunity to tomato yellow leaf curl virus infection in transgenic tomato plants. Transgenic Res 2006; 15: 291-304.

57 Flachowsky H, Szankowski I, Fischer TC et al. Transgenic apple plants overexpressing the Lc gene of maize show an altered growth habit and increased resistance to apple scab and fire blight. Planta 2010; 231: 623-635.

58 Maximova S, Miller C, Antúnez de Mayolo G, Pishak S, Young A, Guiltinan MJ. Stable transformation of Theobroma cacao $\mathrm{L}$. and influence of matrix attachment regions on GFP expression. Plant Cell Rep 2003; 21: 872-883.

59 Mondal S, Dutt M, Grosser J, Dewdney M. Transgenic citrus expressing the antimicrobial gene Attacin E (attE) reduces the susceptibility of 'Duncan' grapefruit to the citrus scab caused by Elsinoë fawcettii. Eur J Plant Pathol 2012; 133: 391-404

60 Qin Y, Teixeira da Silva JA, Zhang L, Zhang S. Transgenic strawberry: state of the art for improved traits. Biotechnol Adv 2008; 26: 219-232.

61 Dhekney SA, Li ZT, Gray DJ. Grapevines engineered to express cisgenic Vitis vinifera thaumatin-like protein exhibit fungal disease resistance. In Vitro Cell Dev Biol Plant 2011; 47: 458-466.

62 Marchant, R, Davey MR, Lucas JA et al. Expression of a chitinase transgene in rose (Rosa hybrida L.) reduces development of blackspot disease (Diplocarpon rosae Wolf). Mol Breed 1998; 4: 187-194.

63 Li X, Gasic K, Cammue B, Broekaert W, Korban SS. Transgenic rose lines harboring an antimicrobial protein gene, Ace-AMP1, demonstrate enhanced resistance to powdery mildew (Sphaerotheca pannosa). Planta 2003; 218: 226-232. 
64 Graham IA, Besser K, Blumer S et al. The genetic map of Artemisia annua L. identifies loci affecting yield of the antimalarial drug artemisinin. Science 2010; 327: 328-331.

65 McCafferty HR, Moore PH, Zhu YJ. Improved Carica papaya tolerance to carmine spider mite by the expression of Manduca sexta chitinase transgene. Transgenic Res 2006; 15: 337-347.

66 Cao J, Tang JD, Strizhov N, Shelton AM, Earle ED. Transgenic broccoli with high levels of Bacillus thuringiensis Cry1C protein control diamondback moth larvae resistant to Cry1A or Cry1C. Mol Breed 1999; 5: 131-141.

67 Shelton A, Hatch SL, Zhao JZ, Chen M, Earle EB, Cao J. Suppression of diamondback moth using Bt-transgenic plants as a trap crop. Crop Prot 2008; 27: 403-409.

68 Dhekney SA, Litz RE, Amador DAM, Yadav AK. Potential for introducing cold tolerance into papaya by transformation with C-repeat binding factor (CBF) genes. In Vitro Cell Dev Biol Plant 2007; 43: 195-202.

69 Jin Y, Ni DA, Ruan YL. Posttranslational elevation of cell wall invertase activity by silencing its inhibitor in tomato delays leaf senescence and increases seed weight and fruit hexose level. Plant Cell Online 2009; 21: 2072-2089.

70 Hsieh TH, Lee JT, Yang PT et al. Heterology expression of the Arabidopsis C-repeat/ dehydration response element binding factor 1 gene confers elevated tolerance to chilling and oxidative stresses in transgenic tomato. Plant Physiol 2002; 129: 1086-1094.

71 Tillett RL, Wheatley MD, Tattersall EA, Schlauch KA, Cramer GR, Cushman JC. The Vitis vinifera $C$-repeat binding protein 4 (VVCBF4) transcriptional factor enhances freezing tolerance in wine grape. Plant Biotechnol J 2012; 10: 105-124.

72 Wisniewski M, Norelli J, Bassett C, Artlip T, Macarisin D. Ectopic expression of a novel peach (Prunus persica) CBF transcription factor in apple (Malus $\times$ domestica) results in short-day induced dormancy and increased cold hardiness. Planta 2011; 233: 971-983.

73 Li F, Guo S, Zhao Y, Chen D, Chong K, Xu Y. Overexpression of a homopeptide repeat-containing bHLH protein gene (OrbHLH001) from Dongxiang Wild Rice confers freezing and salt tolerance in transgenic Arabidopsis. Plant Cell Rep 2010; 29: 977-986.

74 Tian L, Tan L, Liu F, Cai H, Sun C. Identification of quantitative trait loci associated with salt tolerance at seedling stage from Oryza rufipogon. J Genet Genomics 2011; 38: 593-601.

75 Gaxiola RA, Li J, Undurraga S et al. Drought-and salt-tolerant plants result from overexpression of the AVP1 $\mathrm{H}^{+}$-pump. Proc Natl Acad Sci USA 2001; 98: 1144411449.

76 Dandekar AM, Teo G, Defilippi BG et al. Effect of down-regulation of ethylene biosynthesis on fruit flavor complex in apple fruit. Transgenic Res 2004; 13: 373-384.

77 Tieman DM, Harriman RW, Ramamohan G, Handa AK. An antisense pectin methylesterase gene alters pectin chemistry and soluble solids in tomato fruit Plant Cell Online 1992; 4: 667-679.

78 Klee HJ, Hayford MB, Kretzmer KA, Barry GF, Kishore GM. Control of ethylene synthesis by expression of a bacterial enzyme in transgenic tomato plants. Plant Cell Online 1991; 3: 1187-1193.

79 Sheehy RE, Kramer M, Hiatt WR. Reduction of polygalacturonase activity in tomato fruit by antisense RNA. Proc Natl Acad Sci USA 1988; 85: 8805-8809.

80 Bruening G, Lyons J. The case of the FLAVR SAVR tomato. Calif Agric 2000; 54: 6-7.

81 Xiong AS, Yao QH, Peng RH, Li X, Han PL, Fan HQ. Different effects on ACC oxidase gene silencing triggered by RNA interference in transgenic tomato. Plant Cell Rep 2005; 23: 639-646.

82 Meli VS, Ghosh S, Prabha TN, Chakraborty N, Chakraborty S, Datta A. Enhancement of fruit shelf life by suppressing $\mathrm{N}$-glycan processing enzymes. Proc Natl Acad Sci USA 2010; 107: 2413-2418.

83 Lloyd AM, Walbot V, Davis RW. Arabidopsis and Nicotiana anthocyanin production activated by maize regulators $\mathrm{R}$ and $\mathrm{C} 1$. Science 1992; 258: 1773-1775.

84 Bradley JM, Davies KM, Deroles SC, Bloor SJ, Lewis DH. The maize Lc regulatory gene up-regulates the flavonoid biosynthetic pathway of Petunia. Plant J 1998; 13: 381-392.

85 Ueyama Y, Suzukib K, Fukuchi-Mizutani M et al. Molecular and biochemical characterization of torenia flavonoid 3'-hydroxylase and flavone synthase II and modification of flower color by modulating the expression of these genes. Plant Sci 2002; 163: 253-263.

86 Liu G, Sánchez-Fernández RO, Li ZS, Rea PA. Enhanced multispecificity of Arabidopsis vacuolar multidrug resistance-associated protein-type ATP-binding cassette transporter, AtMRP2. J Biol Chem 2001; 276: 8648-8656.

87 Nakagawa $\mathrm{H}$, Jiang CJ, Sakakibara $\mathrm{H}$ et al. Overexpression of a petunia zinc-finger gene alters cytokinin metabolism and plant forms. Plant $J$ 2005; 41: 512-523.

88 Cobb D, Schneiter N, Guo S, Humiston GA, Harriman B, Bolar J. Flower specific expression of an ethylene receptor (ETR1-1) confers ethylene insensitivity in transgenic petunia. In: Proceedings of the XXVIth International Horticultural Congress; 11-17 August; Toronto, Canada. (ISHS, Leuven, Belgium), 2002, p. 83.
89 Lütken H, Clarke JL, Müller R. Genetic engineering and sustainable production of ornamentals: current status and future directions. Plant Cell Rep 2012; 31: 11411157.

90 Lewinsohn E, Schalechet F, Wilkinson J et al. Enhanced levels of the aroma and flavor compound S-linalool by metabolic engineering of the terpenoid pathway in tomato fruits. Plant Physiol 2001; 127: 1256-1265.

91 Maiti IB, Gowda S, Kiernan J, Ghosh SK, Shepherd RJ. Promoter/leader deletion analysis and plant expression vectors with the figwort mosaic virus (FMV) full length transcript (FLt) promoter containing single or double enhancer domains. Transgenic Res 1997; 6: 143-156.

92 Venter M. Synthetic promoters: genetic control through cis engineering. Trends Plant Sci 2007; 12: 118-124.

93 Ranjan R, Patro S, Kumari S, Kumar D, Dey N, Maiti IB. Efficient chimeric promoters derived from full-length and sub-genomic transcript promoters of Figwort mosaic virus (FMV). J Biotechnol 2011; 152: 58-62.

94 Acharya S, Ranjan R, Pattanaik S, Maiti IB, Dey N. Efficient chimeric plant promoters derived from plant infecting viral promoter sequences. Planta 2014; 239: 381 396.

95 Vaccari I, Martinelli L. Evaluation of the phosphomannose isomerase-based selection system for gene transfer in grape. Vitis 2009; 48: 137-144.

96 Schenk PM, Remans T, Sági L et al. Promoters for pregenomic RNA of banana streak badnavirus are active for transgene expression in monocot and dicot plants. Plant Mol Biol 2001; 47: 399-412.

97 Li Z, Gmitter F Jr, Grosser J, Chen C, Gray D. Isolation and characterization of a novel anthocyanin-promoting MYBA gene family in Citrus. Tree Genet Genomes 2012; 8: 675-685.

98 Masura SS, Parveez GK, Ismail I. Isolation and characterization of oil palm constitutive promoter derived from ubiquitin extension protein (uep1) gene. New Biotechnol 2010; 27: 289-299.

99 Kamo K. Long-term expression of the uidA gene in Gladiolus plants under control of either the ubiquitin, rolD, mannopine synthase, or cauliflower mosaic virus promoters following three seasons of dormancy. Plant Cell Rep 2003; 21: 797-803.

100 Annadana S, Mlynárová L, Udayakumar M, de Jong J, Nap JP. The potato Lhca3. St. 1 promoter confers high and stable transgene expression in chrysanthemum, in contrast to CaMV-based promoters. Mol Breed 2002; 8: 335-344.

101 Kasuga M, Liu Q, Miura S, Yamaguchi-Shinozaki K, Shinozaki K. Improving plant drought, salt, and freezing tolerance by gene transfer of a single stress-inducible transcription factor. Nat Biotechnol 1999; 17: 287-291.

102 Deikman J, Kline R, Fischer RL. Organization of ripening and ethylene regulatory regions in a fruit-specific promoter from tomato (Lycopersicon esculentum). Plant Physiol 1992; 100: 2013-2017.

103 Deikman J, Xu R, KneissI ML, Ciardi JA, Kim KN, Pelah D. Separation of cis elements responsive to ethylene, fruit development, and ripening in the $5^{\prime}$-flanking region of the ripening-related E8 gene. Plant Mol Biol 1998; 37: 1001-1011.

104 Atkinson RG, Bolitho KM, Wright MA, Iturriagagoitia-Bueno T, Reid SJ, Ross GS Apple ACC-oxidase and polygalacturonase: ripening-specific gene expression and promoter analysis in transgenic tomato. Plant Mol Biol 1998; 38: 449-460.

105 Barry CS, Blume B, Bouzayen M, Cooper W, Hamilton AJ, Grierson D. Differential expression of the 1-aminocyclopropane-1-carboxylate oxidase gene family of tomato. Plant J 1996; 9: 525-535.

106 Choudhury SR, Singh SK, Roy S, Sengupta DN. An insight into the sequential, structural and phylogenetic properties of banana 1-aminocyclopropane-1carboxylate synthase 1 and study of its interaction with pyridoxal-5'-phosphate and aminoethoxyvinylglycine. J Biosci 2010; 35: 281-294.

107 Moon H, Callahan AM. Developmental regulation of peach ACC oxidase promoter-GUS fusions in transgenic tomato fruits. J Exp Botany 2004; 55: 1519 1528.

108 Hiwasa-Tanase K, Kuroda H, Hirai T, Aoki K, Takane K, Ezura H. Novel promoters that induce specific transgene expression during the green to ripening stages of tomato fruit development. Plant Cell Rep 2012; 31: 1415-1424.

109 Karaaslan M, Hrazdina G. Characterization of an expansin gene and its ripeningspecific promoter fragments from sour cherry (Prunus cerasus L.) cultivars. Acto Physiol Plant 2010; 32: 1073-1084.

110 Unni SC, Vivek PJ, Maju TT, Varghese RT, Soniya EV. Molecular cloning and characterization of fruit specific promoter from Cucumis sativus L. Am J Mol Biol 2012; 2: 132.

111 Wu T, Qin ZW, Feng Z, Zhou XY, Xin M, Du YL. Functional analysis of the promoter of a female-specific cucumber CsACS1G gene. Plant Mol Biol Rep 2012; 30: 235 241.

112 Bustamante CA, Civello PM, Martínez GA. Cloning of the promoter region of $\beta$ xylosidase ( $F a X y / 1)$ gene and effect of plant growth regulators on the expression of FaXyl1 in strawberry fruit. Plant Sci 2009; 177: 49-56.

113 Rahim MA, Busatto N, Trainotti L. Regulation of anthocyanin biosynthesis in peach fruits. Planta 2014; in press. 
114 Yamagata H, Yonesu K, Hirata A, Aizono Y. TGTCACA motif is a novel cis-regulatory enhancer element involved in fruit-specific expression of the cucumisin gene. J Biol Chem 2002; 277: 11582-11590.

115 Yin $\mathrm{T}, \mathrm{Wu} \mathrm{H}$, Zhang $\mathrm{S}$ et al. Two negative cis-regulatory regions involved in fruitspecific promoter activity from watermelon (Citrullus vulgaris S.). J Exp Botany 2009; 60: 169-185.

116 Choudhury SR, Roy S, Das R, Sengupta DN. Differential transcriptional regulation of banana sucrose phosphate synthase gene in response to ethylene, auxin, wounding, low temperature and different photoperiods during fruit ripening and functional analysis of banana SPS gene promoter. Planta 2008; 229: 207-223.

117 Sorkina A, Bardosh G, Liu YZ et al. Isolation of a citrus promoter specific for reproductive organs and its functional analysis in isolated juice sacs and tomato. Plant Cell Rep 2011; 30: 1627-1640.

118 Endo T, Shimada T, Fujii H, Moriguchi T, Omura M. Promoter analysis of a type 3 metallothionein-like gene abundant in Satsuma mandarin (Citrus unshiu Marc.) fruit. Sci Hort 2007; 112: 207-214.

119 Omidvar V, Abdullah SN, Izadfard A, Ho CL, Mahmood M. The oil palm metallothionein promoter contains a novel AGTTAGG motif conferring its fruitspecific expression and is inducible by abiotic factors. Planta 2010; 232: 925-936.

120 Bogs J, Jaffé FW, Takos AM, Walker AR, Robinson SP. The grapevine transcription factor VvMYBPA1 regulates proanthocyanidin synthesis during fruit development Plant Physiol 2007; 143: 1347-1361.

121 Palapol Y, Ketsa S, Lin-Wang K, Ferguson IB, Allan AC. A MYB transcription factor regulates anthocyanin biosynthesis in mangosteen (Garcinia mangostana L.) fruit during ripening. Planta 2009; 229: 1323-1334.

122 Takos AM, Robinson SP, Walker AR. Transcriptional regulation of the flavonoid pathway in the skin of dark-grown 'Cripps' Red' apples in response to sunlight J Hort Sci Biotechnol 2006; 81: 735-744.

123 Kobayashi S, Goto-Yamamoto N, Hirochika H. Retrotransposon-induced mutations in grape skin color. Science 2004; 304: 982-982.

124 Gollop R, Even S, Colova-Tsolova V, Perl A. Expression of the grape dihydroflavonol reductase gene and analysis of its promoter region. J Exp Botany 2002; 53: 1397 1409.

125 Lai B, Li XJ, Hu B et al. LCMYB1 is a key determinant of differential anthocyanin accumulation among genotypes, tissues, developmental phases and $A B A$ and light stimuli in Litchi chinensis. PloS ONE 2014; 9: e86293.

126 Yang Q, Yuan D, Shi L et al. Functional characterization of the Gentiana lutea zeaxanthin epoxidase (GIZEP) promoter in transgenic tomato plants. Transgenic Res 2012; 21: 1043-1056.

127 Bhat D, Anjanasree K, Lenka S, Bansal K. Isolation and characterization of fruitspecific promoters ACS4 and EXP1 from tomato (Solanum lycopersicum L). J Plant Biochem Biotechnol 2010; 19: 51-57.

128 Lin E, Burns DJ, Gardner RC. Fruit developmental regulation of the kiwifruit actinidin promoter is conserved in transgenic petunia plants. Plant $\mathrm{Mol}$ Biol 1993; 23: 489-499.

129 Litz RE, Padilla G. Genetic transformation of fruit trees. In: Genomics of Tree Crops. Berlin: Springer, 2012: 117-153.

130 Lücker $\mathrm{J}$ et al. Monoterpene biosynthesis in lemon (Citrus limon). Eur J Biochem 2002; 269: 3160-3171.

131 Rai MK, Shekhawat N. Recent advances in genetic engineering for improvement of fruit crops. Plant Cell Tissue Organ Culture (PCTOC) 2014; 116: 1-15.

132 Hirai T, Duhita N, Hiwasa-Tanase K, Ezura H. Cultivation under salt stress increases the concentration of recombinant miraculin in transgenic tomato fruit, resulting in an increase in purification efficiency. Plant Biotechnol 2011; 28: 387-392.

133 Mehta RA, Cassol T, Li N, Ali N, Handa AK, Mattoo AK. Engineered polyamine accumulation in tomato enhances phytonutrient content, juice quality, and vine life. Nat Biotechnol 2002; 20: 613-618.

134 Carmi N, Salts Y, Dedicova B, Shabtai S, Barg R. Induction of parthenocarpy in tomato via specific expression of the rolB gene in the ovary. Planta 2003; 217: 726-735.

135 Kesanakurti D, Kolattukudy PE, Kirti PB. Fruit-specific overexpression of woundinduced tap1 under E8 promoter in tomato confers resistance to fungal pathogens at ripening stage. Physiol Plant 2012; 146: 136-148.

136 Raharjo S, Witjaksono ED, Gomez-Lim M, Suarez I, Litz R. Genetic transformation of avocado. ISHS Acta Hort 2003; 692: 115-118.

137 Costantini E, Landi L, Silvestroni O, Pandolfini T, Spena A, Mezzetti B. Auxin synthesis-encoding transgene enhances grape fecundity. Plant Physiol 2007; 143: 1689-1694.

138 Mezzetti B, Landi L, Pandolfini T, Spena A. The defH9-iaaM auxin-synthesizing gene increases plant fecundity and fruit production in strawberry and raspberry. BMC Biotechnol 2004; 4: 4.

139 Thomas TL. Gene expression during plant embryogenesis and germination: an overview. Plant Cell 1993; 5: 1401-1410.
140 Bustos MM, Guiltinan MJ, Jordano J, Begum D, Kalkan FA, Hall TC. Regulation of beta-glucuronidase expression in transgenic tobacco plants by an A/T-rich, cisacting sequence found upstream of a French bean beta-phaseolin gene. Plant Cell 1989; 1: 839-853.

141 van der Geest AH, Hall TC. A 68 bp element of the beta-phaseolin promoter functions as a seed-specific enhancer. Plant Mol Biol 1996; 32: 579-588.

142 Fauteux F, Stromvik MV. Seed storage protein gene promoters contain conserved DNA motifs in Brassicaceae, Fabaceae and Poaceae. BMC Plant Biol 2009; 9: 126.

143 Shirsat A, Wilford N, Croy R, Boulter D. Sequences responsible for the tissue specific promoter activity of a pea legumin gene in tobacco. Mol Gen Genet 1989; 215: 326-331.

144 Kroj T, Savino G, Valon C, Giraudat J, Parcy F. Regulation of storage protein gene expression in Arabidopsis. Development 2003; 130: 6065-6073.

145 Li ZT, Gray D. Isolation by improved thermal asymmetric interlaced PCR and characterization of a seed-specific $2 S$ albumin gene and its promoter from grape (Vitis vinifera L.). Genome 2005; 48: 312-320.

146 Dasgupta S, Dasgupta J, Mandal RK. Cloning and sequencing of 5 ' flanking sequence from the gene encoding $2 S$ storage protein, from two Brassica species. Gene 1993; 133: 301-302.

147 Vincentz M, Leite A, Neshich G et al. ACGT and vicilin core sequences in a promoter domain required for seed-specific expression of a $2 S$ storage protein gene are recognized by the opaque-2 regulatory protein. Plant Mol Biol 1997; 34: 879-889.

148 Ezcurra I, Wycliffe P, Nehlin L, Ellerstrom M, Rask, L. Transactivation of the Brassica napus napin promoter by $A B I 3$ requires interaction of the conserved $B 2$ and $B 3$ domains of $A B I 3$ with different cis-elements: $B 2$ mediates activation through an $A B R E$, whereas $B 3$ interacts with an RY/G-box. Plant J 2000; 24: 57-66.

149 Bies-Etheve N, da Silva Conceicao A, Giraudat J et al. Importance of the B2 domain of the Arabidopsis $\mathrm{ABI} 3$ protein for Em and $2 \mathrm{~S}$ albumin gene regulation. Plant $\mathrm{Mol}$ Biol 1999; 40: 1045-1054.

150 Stålberg K, Ellerstöm M, Ezcurra I, Ablov S, Rask L. Disruption of an overlapping Ebox/ABRE motif abolished high transcription of the napA storage-protein promoter in transgenic Brassica napus seeds. Planta 1996; 199: 515-519.

151 Rask L, Ellerström M, Ezcurra I, Stålberg K, Wycliffe P. Seed-specific regulation of the napin promoter in Brassica napus. J Plant Physiol 1998; 152: 595-599.

152 Shirsat $\mathrm{AH}$. A transposon-like structure in the $5^{\prime}$ flanking sequence of a legumin gene from Pisum sativum. Mol Gen Genet 1988; 212: 129-133.

153 Lycett GW, Croy RR, Shirsat AH, Richards DM, Boulter D. The 5'-flanking regions of three pea legumin genes: comparison of the DNA sequences. Nucleic Acids Res 1985; 13: 6733-6743.

154 Rerie WG, Whitecross M, Higgins TJ. Developmental and environmental regulation of pea legumin genes in transgenic tobacco. Mol Gen Genet 1991; 225: $148-157$.

155 Shirsat AH, Meakin PJ, Gatehouse JA. Sequences $5^{\prime}$ to the conserved 28 bp Leg box element regulate the expression of pea seed storage protein gene legA. Plant Mol Biol 1990; 15: 685-693.

156 Baumlein H, Boerjan W, Nagy I, Panitz R, Inzé D, Wobus U. Upstream sequences regulating legumin gene expression in heterologous transgenic plants. Mol Gen Genet 1991; 225: 121-128.

157 Baumlein H, Nagy I, Villarroel R, Inze D, Wobus U. Cis-analysis of a seed protein gene promoter: the conservative RY repeat CATGCATG within the legumin box is essential for tissue-specific expression of a legumin gene. Plant J 1992; 2: 233-239.

158 Fiedler U, Filistein R, Wobus U, Baumlein H. A complex ensemble of cis-regulatory elements controls the expression of a Vicia faba non-storage seed protein gene. Plant Mol Biol 1993; 22: 669-679.

159 Kawagoe $Y$, Murai N. Four distinct nuclear proteins recognize in vitro the proximal promoter of the bean seed storage protein beta-phaseolin gene conferring spatial and temporal control. Plant J 1992; 2: 927-936.

160 Kawagoe Y, Campbell BR, Murai N. Synergism between CACGTG (G-box) and CACCTG cis-elements is required for activation of the bean seed storage protein beta-phaseolin gene. Plant $J$ 1994; 5: 885-890.

161 Bustos MM, Begum D, Kalkan FA, Battraw MJ, Hall TC. Positive and negative cisacting DNA domains are required for spatial and temporal regulation of gene expression by a seed storage protein promoter. EMBO J 1991; 10: 1469-1479.

162 Chung HJ, Fu H, Thomas T. Abscisic acid-inducible nuclear proteins bind to bipartite promoter elements required for $A B A$ response and embryo-regulated expression of the carrot Dc3 gene. Planta 2005; 220: 424-433.

163 Kim SY, Chung HJ, Thomas TL. Isolation of a novel class of bZIP transcription factors that interact with ABA-responsive and embryo-specification elements in the Dc3 promoter using a modified yeast one-hybrid system. Plant $J$ 1997; 11: 1237-1251.

164 Chak RKF, Thomas TL, Quatrano RS, Rock CD. The genes ABI1 and ABI2 are involved in abscisic acid- and drought-inducible expression of the Daucus carota L. Dc3 promoter in guard cells of transgenic Arabidopsis thaliana (L.) Heynh. Planta 2000; 210: 875-883. 
165 Chak RK, Thomas TL, Quatrano RS, Rock CD. The genes ABI1 and ABI2 are involved in abscisic acid-and drought-inducible expression of the Daucus carota L. Dc3 promoter in guard cells of transgenic Arabidopsis thaliana (L.) Heynh. Planta 2000; 210: $875-883$.

166 Vivekananda J, Drew MC, Thomas TL. Hormonal and environmental regulation of the carrot lea-class gene Dc3. Plant Physiol 1992; 100: 576-581.

167 Yamamoto S, Nishihara M, Morikawa H, Yamauchi D, Minamikawa T. Promoter analysis of seed storage protein genes from Canavalia gladiata D.C. Plant Mol Biol 1995; 27: 729-741.

168 de Pater S, Pham K, Klitsie I, Kijne J. The 22 bp W1 element in the pea lectin promoter is necessary and, as a multimer, sufficient for high gene expression in tobacco seeds. Plant Mol Biol 1996; 32: 515-523.

169 de Pater S, Katagiri F, Kijne J, Chua NH. bZIP proteins bind to a palindromic sequence without an ACGT core located in a seed-specific element of the pea lectin promoter. Plant J 1994; 6: 133-140.

170 Bogue MA, Vonder Haar RA, Nuccio ML, Griffing LR, Thomas TL. Developmentally regulated expression of a sunflower $11 \mathrm{~S}$ seed protein gene in transgenic tobacco. Mol Gen Genet 1990; 222: 49-57.

171 Nishikawa F, Endo T, Shimada T et al. Isolation and characterization of a citrus FT/ TFL1 homologue (CUMFT1), which shows quantitatively preferential expression in Citrus seeds. J Jpn Soc Hort Sci 2008; 77: 38-46.

172 Sengupta-Gopalan C, Reichert NA, Barker RF, Hall TC, Kemp JD. Developmentally regulated expression of the bean beta-phaseolin gene in tobacco seed. Proc Natl Acad Sci USA 1985; 82: 3320-3324.

173 Ouwerkerk PB, Memelink J. A G-box element from the Catharanthus roseus strictosidine synthase (Str) gene promoter confers seed-specific expression in transgenic tobacco plants. Mol Gen Genet 1999; 261: 635-643.

174 Endress PK. Origins of flower morphology. J Exp Zool 2001; 291: 105-115.

175 Theiszen G, Saedler H. Plant biology: floral quartets. Nature 2001; 409: 469-471.

176 Coen ES, Romero JM, Doyle S, Elliott R, Murphy G, Carpenter R. Floricaula: a homeotic gene required for flower development in antirrhinum majus. Cell 1990; 63: 1311-1322.

177 Yang $Y$, Singer S, Liu Z. Petunia AGAMOUS enhancer-derived chimeric promoters specify a carpel, stamen, and petal-specific expression pattern sufficient for engineering male and female sterility in tobacco. Plant Mol Biol Rep 2011; 29: 162-170.

178 Bovy AG, Angenent GC, Dons HJ, van Altvorst AC. Heterologous expression of the Arabidopsis etr1-1 allele inhibits the senescence of carnation flowers. Mol Breed 1999; 5: 301-308.

179 Chang $\mathrm{H}$, Jones ML, Banowetz GM, Clark DG. Overproduction of cytokinins in petunia flowers transformed with PSAG12-IPT delays corolla senescence and decreases sensitivity to ethylene. Plant Physiol 2003; 132: 2174-2183.

180 Serek M, Woltering E, Sisler E, Frello S, Sriskandarajah S. Controlling ethylene responses in flowers at the receptor level. Biotechnol Adv 2006; 24: 368-381.

181 Tanaka Y, Katsumoto Y, Brugliera F, Mason J. Genetic engineering in floriculture. Plant Cell Tissue Organ Culture 2005; 80: 1-24.

182 Savin KW, Baudinette SC, Graham MW et al. Antisense ACC oxidase RNA delays carnation petal senescence. HortScience 1995; 30: 970-972.

183 Aida R, Kishimoto S, Tanaka Y, Shibata M. Modification of flower color in torenia(Torenia fournieri Lind.) by genetic transformation. Plant Sci 2000; 153 : 33-42.

184 Tanaka Y, Tsuda S, Kusumi T. Metabolic engineering to modify flower color. Plant Cell Physiol 1998; 39: 1119-1126.

185 Zuker A, Tzfira T, Meir H et al. Modification of flower color and fragrance by antisense suppression of the flavanone 3-hydroxylase gene. Mol Breed 2002; 9: 33-41.

186 Verdonk JC, Haring MA, van Tunen AJ, Schuurink RC. ODORANT1 regulates fragrance biosynthesis in petunia flowers. Plant Cell Online 2005; 17: 1612-1624.

187 Aranovich D, Lewinsohn E, Zaccai M. Post-harvest enhancement of aroma in transgenic lisianthus (Eustoma grandiflorum) using the Clarkia breweri benzyl alcohol acetyltransferase (BEAT) gene. Postharvest Biol Technol 2007; 43: 255-260.

188 Mariani C, Beuckeleer MD, Truettner J, Leemans J, Goldberg RB. Induction of male sterility in plants by a chimaeric ribonuclease gene. Nature 1990; 347: 737-741.

189 Goetz M, Godt DE, Guivarc'h A, Kahmann U, Chriqui D, Roitsch T. Induction of male sterility in plants by metabolic engineering of the carbohydrate supply. Proc Natl Acad Sci USA 2001; 98: 6522-6527.

190 Mariani C, Gossele V, de Beuckeleer M et al. A chimaeric ribonuclease-inhibitor gene restores fertility to male sterile plants. Nature 1992; 357: 384-387.

191 Goldman M, Goldberg R, Mariani C. Female sterile tobacco plants are produced by stigma-specific cell ablation. EMBO J 1994; 13: 2976.

192 Mitsuda N, Hiratsu K, Todaka D et al. Efficient production of male and female sterile plants by expression of a chimeric repressor in Arabidopsis and rice. Plant Biotechnol J 2006; 4: 325-332.

193 Koes R, Spelt CE, Reif HJ, van den Elzen PJ, Veltkamp E, Mol JN. Floral tissue of Petunia hybrida (V30) expresses only one member of the chalcone synthase multigene family. Nucleic Acids Res 1986; 14: 5229-5239.
194 Ferrer JL, Jez JM, Bowman ME, Dixon RA, Noel JP. Structure of chalcone synthase and the molecular basis of plant polyketide biosynthesis. Nat Struct Mol Biol 1999; 6: 775-784.

195 Faktor O, Loake G, Dixon RA, Lamb CJ. The G-box and H-box in a 39 bp region of a French bean chalcone synthase promoter constitute a tissue-specific regulatory element. Plant J 1997; 11: 1105-1113.

196 Lipphardt S, Brettschneider R, Kreuzaler F, Schell J, Dangl JL. UV-inducible transient expression in parsley protoplasts identifies regulatory cis-elements of a chimeric Antirrhinum majus chalcone synthase gene. EMBO J 1988; 7: 4027.

197 Koes RE, van Blokland R, Quattrocchio F, van Tunen AJ, Mol J. Chalcone synthase promoters in petunia are active in pigmented and unpigmented cell types. Plant Cell Online 1990; 2: 379-392.

198 Schmid J, Doerner PW, Clouse SD, Dixon RA, Lamb CJ. Developmental and environmental regulation of a bean chalcone synthase promoter in transgenic tobacco. Plant Cell Online 1990; 2: 619-631.

199 Loake GJ, Faktor O, Lamb CJ, Dixon RA. Combination of H-box [CCTACC(N)7CT] and G-box (CACGTG) cis elements is necessary for feed-forward stimulation of a chalcone synthase promoter by the phenylpropanoid-pathway intermediate $\mathrm{p}$ coumaric acid. Proc Natl Acad Sci USA 1992; 89: 9230-9234.

200 Faktor O, Kooter JM, Loake GJ, Dixone RA, Lamb CJ. Differential utilization of regulatory cis-elements for stress-induced and tissue-specific activity of a French bean chalcone synthase promoter. Plant Sci 1997; 124: 175-182.

201 Harrison MJ, Lawton MA, Lamb CJ, Dixon RA. Characterization of a nuclear protein that binds to three elements within the silencer region of a bean chalcone synthase gene promoter. Proc Natl Acad Sci USA 1991; 88: 2515-2519.

202 Harrison M, Choudhary A, Dubery I, Lamb C, Dixon R. Stress responses in alfalfa (Medicago sativa L.). 8. Cis-elements and trans-acting factors for the quantitative expression of a bean chalcone synthase gene promoter in electroporated alfalfa protoplasts. Plant Mol Biol 1991; 16: 877-890.

203 van der Meer IM, Spelt CE, Mol JN, Stuitje AR. Promoter analysis of the chalcone synthase (chsA) gene of Petunia hybrida: a 67 bp promoter region directs flowerspecific expression. Plant Mol Biol 1990; 15: 95-109.

204 Tsukaya H, Ohshima T, Naito S, Chino M, Komeda Y. Sugar-dependent expression of the CHS-A gene for chalcone synthase from petunia in transgenic Arabidopsis. Plant Physiol 1991; 97: 1414-1421.

205 van der Meer I, Spelt C, Mol JM, Stuitje A. Promoter analysis of the chalcone synthase (chsA) gene of Petunia hybrida: a $67 \mathrm{bp}$ promoter region directs flower-specific expression. Plant Mol Biol 1990; 15: 95-109.

206 Fritze K, Staiger D, Czaja I, Walden R, Schell J, Wing D. Developmental and UV light regulation of the snapdragon chalcone synthase promoter. Plant Cell Online 1991 3: 893-905.

207 Wang J, Letham DS, Cornish E, Stevenson KR. Studies of cytokinin action and metabolism using tobacco plants expressing either the ipt or the gus gene controlled by a chalcone synthase promoter. I. Developmental features of the transgenic plants. Funct Plant Biol 1997; 24: 661-672.

208 Staiger D, Kaulen $\mathrm{H}$, Schell J. A nuclear factor recognizing a positive regulatory upstream element of the Antirrhinum majus chalcone synthase promoter. Plant Physiol 1990; 93: 1347-1353.

209 Staiger D, Kaulen H, Schell J. A CACGTG motif of the Antirrhinum majus chalcone synthase promoter is recognized by an evolutionarily conserved nuclear protein Proc Natl Acad Sci USA 1989; 86: 6930-6934.

210 Kobayashi H, Oikawa Y, Koiwa H, Yamamura S. Flower-specific gene expression directed by the promoter of a chalcone synthase gene from Gentiana triflora in Petunia hybrida. Plant Sci 1998; 131: 173-180.

211 Block A, Dangl JL, Hahlbrock K, Schulze-Lefert P. Functional borders, genetic fine structure, and distance requirements of cis elements mediating light responsiveness of the parsley chalcone synthase promoter. Proc Natl Acad Sci USA 1990; 87: 5387-5391.

212 Annadana S, Beekwilder MJ, Kuipers G et al. Cloning of the chrysanthemum UEP1 promoter and comparative expression in florets and leaves of Dendranthema grandiflora. Transgenic Res 2002; 11: 437-445.

213 Sassa H, Ushijima K, Hirano H. A pistil-specific thaumatin/PR5-like protein gene of Japanese pear (Pyrus serotina): sequence and promoter activity of the 5 ' region in transgenic tobacco. Plant Mol Biol 2002; 50: 371-377.

214 Sassa $\mathrm{H}$, Hirano $\mathrm{H}$. Style-specific and developmentally regulated accumulation of a glycosylated thaumatin/PR5-like protein in Japanese pear (Pyrus serotina Rehd.). Planta 1998; 205: 514-521.

215 Kuboyama T. A novel thaumatin-like protein gene of tobacco is specifically expressed in the transmitting tissue of stigma and style. Sex Plant Reprod 1998, 11: $251-256$.

216 Schaart J, Salentijn E, Krens F. Tissue-specific expression of the $\beta$-glucuronidase reporter gene in transgenic strawberry (Fragaria $\times$ ananassa) plants. Plant Cell Rep 2002; 21: 313-319. 
217 Castillejo C, de la Fuente Jl, lannetta P, Botella MÁ, Valpuesta V. Pectin esterase gene family in strawberry fruit: study of FaPE1, a ripening-specific isoform. $J$ Exp Botany 2004; 55: 909-918.

218 Hill TA, Day CD, Zondlo SC, Thackeray AG, Irish VF. Discrete spatial and temporal cis-acting elements regulate transcription of the Arabidopsis floral homeotic gene APETALA3. Development 1998; 125: 1711-1721.

219 Yang Y, Singer SD, Liu Z. Petunia AGAMOUS enhancer-derived chimeric promoters specify a carpel, stamen, and petal-specific expression pattern sufficient for engineering male and female sterility in tobacco. Plant $\mathrm{Mol} B i o l$ Rep 2011; 29: 162-170.

220 Nacken WK, Huijser P, Beltran JP, Saedler H, Sommer H. Molecular characterization of two stamen-specific genes, tap 1 and fill, that are expressed in the wild type, but not in the deficiens mutant of Antirrhinum majus. Mol Gen Genet 1991; 229 : 129-136.

221 Choi YO, Kim SS, Lee S et al. Isolation and promoter analysis of anther-specific genes encoding putative arabinogalactan proteins in Malus $\times$ domestica. Plant Cell Rep 2010; 29: 15-24.

222 van Tunen AJ, Mur LA, Brouns CS, Rienstra JD, Koes RE, Moi JN. Pollen-and antherspecific chi promoters from petunia: tandem promoter regulation of the chiA gene. Plant Cell Online 1990; 2: 393-401.

223 Twell D, Yamaguchi J, McCormick S. Pollen-specific gene expression in transgenic plants: coordinate regulation of two different tomato gene promoters during microsporogenesis. Development 1990; 109: 705-713.

224 Ficker M, Wemmer T, Thompson R. A promoter directing high level expression in pistils of transgenic plants. Plant Mol Biol 1997; 35: 425-431.

225 Mccormick S. Molecular analysis of male gametogenesis in plants. Trends Genet 1991; 7: 298-303.

226 Kriete G, Niehaus K, Perlick A, Pühler A, Broer I. Male sterility in transgenic tobacco plants induced by tapetum-specific deacetylation of the externally applied nontoxic compound N-acetyl-L-phosphinothricin. Plant J 1996; 9: 809-818.

227 Guerrero FD, Crossland L, Smutzer GS, Hamilton DA, Mascarenhas JP. Promoter sequences from a maize pollen-specific gene direct tissue-specific transcription in tobacco. Mol Gen Genet 1990; 224: 161-168.

228 Wang Z, Zou YJ, Li XY et al. Cytoplasmic male sterility of rice with boro II cytoplasm is caused by a cytotoxic peptide and is restored by two related PPR motif genes via distinct modes of mRNA silencing. Plant Cell Online 2006; 18: 676-687.

229 Zou JT, Zhan XY, Wu HM, Wang H, Cheung AY. Characterization of a rice pollenspecific gene and its expression. Am J Botany 1994; 81: 552-561.

230 Hernould M, Suharsono S, Litvak S, Araya A, Mouras A. Male-sterility induction in transgenic tobacco plants with an unedited atp9 mitochondrial gene from wheat. Proc Natl Acad Sci USA 1993; 90: 2370-2374.

$231 \mathrm{He}$ S, Abad AR, Gelvin SB, Mackenzie SA. A cytoplasmic male sterility-associated mitochondrial protein causes pollen disruption in transgenic tobacco. Proc Nat Acad Sci USA 1996; 93: 11763-11768.

232 de Block M, Debrouwer D, Moens T. The development of a nuclear male sterility system in wheat. Expression of the barnase gene under the control of tapetum specific promoters. Theor Appl Genet 1997; 95: 125-131.

233 Ariizumi T, Amagai M, Shibata D, Hatakeyama K, Watanabe M, Toriyama K. Comparative study of promoter activity of three anther-specific genes encoding lipid transfer protein, xyloglucan endotransglucosylase/hydrolase and polygalacturonase in transgenic Arabidopsis thaliana. Plant Cell Rep 2002; 21: 90 96.

234 Twell D, Patel S, Sorensen A et al. Activation and developmental regulation of an Arabidopsis anther-specific promoter in microspores and pollen of Nicotiana tabacum. Sex Plant Reprod 1993; 6: 217-224.

235 Paul W, Hodge R, Smartt S, Draper J, Scott R. The isolation and characterisation of the tapetum-specific Arabidopsis thaliana A9 gene. Plant Mol Biol 1992; 19: 611622.

236 de Oliveira DE, Franco LO, Simoens $C$ et al. Inflorescence-specific genes from Arabidopsis thaliana encoding glycine-rich proteins. Plant J 1993; 3: 495-507.

237 Twell D, Wing R, Yamaguchi J, McCormick S. Isolation and expression of an antherspecific gene from tomato. Mol Gen Genet 1989; 217: 240-245.

238 Roque E, Gómez MD, Ellul P et al. The PsEND1 promoter: a novel tool to produce genetically engineered male-sterile plants by early anther ablation. Plant Cell Rep 2007; 26: 313-325.

239 Twell D, Klein TM, Fromm ME, McCormick S. Transient expression of chimeric genes delivered into pollen by microprojectile bombardment. Plant Physio 1989; 91: 1270-1274.

240 Mascarenhas JP. The male gametophyte of flowering plants. Plant Cell 1989; 1 657.

241 Muschietti J, Dircks L, Vancanneyt G, McCormick S. LAT52 protein is essential for tomato pollen development: pollen expressing antisense LAT52 RNA hydrates and germinates abnormally and cannot achieve fertilization. Plant J 1994; 6: 321 338.
242 Bate N, Twell D. Functional architecture of a late pollen promoter: pollen-specific transcription is developmentally regulated by multiple stage-specific and codependent activator elements. Plant Mol Biol 1998; 37: 859-869.

243 Eady C, Lindsey K, Twell D. Differential activation and conserved vegetative cellspecific activity of a late pollen promoter in species with bicellular and tricellular pollen. Plant J 1994; 5: 543-550.

244 Kato H, Xie G, Sato Y, Imai R. Isolation of anther-specific gene promoters suitable for transgene expression in rice. Plant Mol Biol Rep 2010; 28: 381-387.

245 Nishihara $M$, Ito $M$, Tanaka l et al. Expression of the $\beta$-glucuronidase gene in pollen of lily (Lilium longiflorum), tobacco (Nicotiana tabacum), Nicotiana rustica, and peony (Paeonia lactiflora) by particle bombardment. Plant Physiol 1993; 102: 357-361.

246 Miyoshi H, Usami T, Tanaka I. High level of GUS gene expression driven by pollenspecific promoters in electroporated lily pollen protoplasts. Sex Plant Reprod 1995; 8: 205-209.

247 Bhalla PL, Smith N. Agrobacterium tumefaciens-mediated transformation of cauliflower, Brassica oleracea var. botrytis. Mol Breed 1998; 4: 531-541.

248 Xu S, Liu G, Chen R. Characterization of an anther and tapetum-specific gene and its highly specific promoter isolated from tomato. Plant Cell Rep 2006; 25: 231240.

249 Kim H, Park BS, Jin YM, Chung T. Promoter sequences of two homologous pectin esterase genes from Chinese cabbage (Brassica campestris L. ssp. pekinensis) and pollen-specific expression of the GUS gene driven by a promoter in tobacco plants. Mol Cells 1997; 7: 21-27.

250 Gómez MD, Beltrán JP, Cañas LA. The pea END1 promoter drives anther-specific gene expression in different plant species. Planta 2004; 219: 967-981.

251 Boyce CK. The evolutionary history of roots and leaves. In: Vascular Transport in Plants. Amsterdam: Academic Press, 2005: 479-499.

252 Schiefelbein JW, Benfey PN. The development of plant roots: new approaches to underground problems. Plant Cell 1991; 3: 1147.

253 Olsen S, Kemper W. Movement of nutrients to plant roots. Adv Agron 1968; 20: 91151.

254 Lynch J. Root architecture and plant productivity. Plant Physiol 1995; 109: 7.

255 Aiken R, Smucker A. Root system regulation of whole plant growth. Annu Rev Phytopathol 1996; 34: 325-346.

256 Rost TL, Bryant JA. Root organization and gene expression patterns. J Exp Botany 1996; 47: 1613-1628.

257 Rovira A. Interactions between plant roots and soil microorganisms. Annu Rev Microbiol 1965; 19: 241-266.

258 Cook RJ. Advances in plant health management in the twentieth century. Annu Rev Phytopathol 2000; 38: 95-116.

259 Foy CD. Limitations to Plant Root Growth. Berlin: Springer, 1992: 97-149.

260 Neher DA. Role of nematodes in soil health and their use as indicators. J Nematol 2001; 33: 161.

261 Potenza C, Aleman L, Sengupta-Gopalan C. Targeting transgene expression in research, agricultural, and environmental applications: promoters used in plant transformation. In Vitro Cell Dev Biol Plant 2004; 40: 1-22.

262 Yamamoto YT, Taylor CG, Acedo GN, Cheng CL, Conkling MA. Characterization of cis-acting sequences regulating root-specific gene expression in tobacco. Plant Cell Online 1991; 3: 371-382.

263 Jones MO, Kamarainen-Karppinen T, Koskimaki JJ et al. The promoter from SIREO, a highly-expressed, root-specific Solanum lycopersicum gene, directs expression to cortex of mature roots. Funct Plant Biol 2009; 35: 1224-1233.

264 Maurel C, Verdoucq L, Luu DT, Santoni V. Plant aquaporins: membrane channels with multiple integrated functions. Annu Rev Plant Biol 2008; 59: 595-624.

265 Javot H, Maurel C. The role of aquaporins in root water uptake. Ann Botany 2002; 90: 301-313.

266 Chan YL, Prasad V, Sanjaya et al. Transgenic tomato plants expressing an Arabidopsis thionin (Thi2. 1) driven by fruit-inactive promoter battle against phytopathogenic attack. Planta 2005; 221: 386-393.

267 Vaughan SP, James DJ, Lindsey K, Massiah AJ. Characterization of FaRB7, a near root-specific gene from strawberry (Fragaria $\times$ ananassa Duch.) and promoter activity analysis in homologous and heterologous hosts. J Exp Botany 2006; 57: 3901-3910.

268 Yamada S, Nelson DE, Ley E, Marquez S, Bohnert HJ. The expression of an aquaporin promoter from Mesembryanthemum crystallinum in tobacco. Plant Cell Physiol 1997; 38: 1326-1332.

269 Schultze M, Kondorosi A. Regulation of symbiotic root nodule development. Annu Rev Genet 1998; 32: 33-57.

270 Forde BG, Freeman J, Oliver JE, Pineda M. Nuclear factors interact with conserved $A / T$-rich elements upstream of a nodule-enhanced glutamine synthetase gene from French bean. Plant Cell 1990; 2: 925-939.

271 Vieweg MF, Frühling M, Quandt $\mathrm{HJ}$ et al. The promoter of the Vicia faba L. leghemoglobin gene VfLb29 is specifically activated in the infected cells of root 
nodules and in the arbuscule-containing cells of mycorrhizal roots from different legume and nonlegume plants. Mol Plant-Microbe Interact 2004; 17: 62-69.

272 Frühling M, Schröder G, Hohnjec N, Pühler A, Perlick AM, Küster H. The promoter of the Vicia faba L. gene VfEnod 12 encoding an early nodulin is active in cortical cells and nodule primordia of transgenic hairy roots of Vicia hirsuta as well as in the prefixing zone II of mature transgenic V. hirsuta root nodules. Plant Sci 2000; 160: 67-75.

273 Szabados L, Ratet P, Grunenberg B, de Bruijn FJ. Functional analysis of the Sesbania rostrata leghemoglobin glb3 gene $5^{\prime}$-upstream region in transgenic Lotus corniculatus and Nicotiana tabacum plants. Plant Cell Online 1990; 2: 973-986.

274 Vijn I, Christiansen H, Lauridsen P et al. A 200 bp region of the pea ENOD12 promoter is sufficient for nodule-specific and Nod factor induced expression. Plant Mol Biol 1995; 28: 1103-1110.

275 Carsolio C, Campos F, Sánchez F, Rocha-Sosa M. The expression of a chimeric Phaseolus vulgaris nodulin 30-GUS gene is restricted to the rhizobially infected cells in transgenic Lotus corniculatus nodules. Plant Mol Biol 1994; 26: 1995-2001.

276 Kloosterman B, de Koeyer D, Griffiths R et al. Genes driving potato tuber initiation and growth: identification based on transcriptional changes using the $\mathrm{POCl}$ array. Funct Integr Genomics 2008; 8: 329-340.

277 Bachem CW, van der Hoeven RS, de Bruijn SM, Vreugdenhil D, Zabeau M, Visser RG. Visualization of differential gene expression using a novel method of RNA fingerprinting based on AFLP: analysis of gene expression during potato tuber development. Plant J 1996; 9: 745-753.

278 Jefferson R, Goldsbrough A, Bevan M. Transcriptional regulation of a patatin-1 gene in potato. Plant Mol Biol 1990; 14: 995-1006.

279 Grierson C, Du JS, de Torres Zabala M et al. Separate cis sequences and trans factors direct metabolic and developmental regulation of a potato tuber storage protein gene. Plant J 1994; 5: 815-826.

280 Rocha-Sosa M, Sonnewald U, Frommer W, Stratmann M, Schell J, Willmitzer L. Both developmental and metabolic signals activate the promoter of a class I patatin gene. $E M B O$ J 1989; 8: 23.

281 Jefferson R, Goldsbrough A, Bevan M. Transcriptional regulation of a patatin-1 gene in potato. Plant Mol Biol 1990; 14: 995-1006.

282 Liu XJ, Prat S, Willmitzer L, Frommer WB. cis regulatory elements directing tuberspecific and sucrose-inducible expression of a chimeric class I patatin promoter/ GUS-gene fusion. Mol Gen Genet 1990; 223: 401-406.

283 Grierson C, Du JS, de Torres Zabala M et al. Separate cis sequences and trans factors direct metabolic and developmental regulation of a potato tuber storage protein gene. Plant J 1994; 5: 815-826.

284 Farran I, Sánchez-Serrano J, Medina J, Prieto J, Mingo-Castel A. Targeted expression of human serum albumin to potato tubers. Transgenic Res 2002; 11: 337-346.

285 Hattori T, Nakagawa T, Maeshima M, Nakamura K, Asahi T. Molecular cloning and nucleotide sequence of cDNA for sporamin, the major soluble protein of sweet potato tuberous roots. Plant Mol Biol 1985; 5: 313-320.

286 Ohta S, Hattori T, Morikami A, Nakamura K. High-level expression of a sweet potato sporamin gene promoter: $\beta$-glucuroidase (GUS) fusion gene in the stems of transgenic tobacco plants is conferred by multiple cell type-specific regulatory elements. Mol Gen Genet 1991; 225: 369-378.

287 Wang SJ, Lan YC, Chen SF, Chen YM, Yeh KW. Wound-response regulation of the sweet potato sporamin gene promoter region. Plant Mol Biol 2002; 48: 223-231.

288 Hong YF, Liu CY, Cheng KJ et al. The sweet potato sporamin promoter confers high-level phytase expression and improves organic phosphorus acquisition and tuber yield of transgenic potato. Plant Mol Biol 2008; 67: 347-361.

289 Morikami A, Matsunaga R, Tanaka Y, Suzuki S, Mano S, Nakamura K. Two cis-acting regulatory elements are involved in the sucrose-inducible expression of the sporamin gene promoter from sweet potato in transgenic tobacco. Mol Genet Genomics 2005; 272: 690-699.

$290 \mathrm{Ye} \mathrm{ZH}$. Vascular tissue differentiation and pattern formation in plants. Annu Rev Plant Biol 2002; 53: 183-202.

291 Aloni R. The induction of vascular tissues by auxin and cytokinin. In: Plant Hormones. Amsterdam: Springer, 1995: 531-546.

292 Tyree MT, Zimmermann MH. Xylem Structure and the Ascent of Sap. Berlin: Springer, 2002.

293 Crafts AS, Crisp CE. Phloem Transport in Plants. San Francisco, CA: WH Freeman \& Co., 1971.

294 van Bel AJ. The phloem, a miracle of ingenuity. Plant Cell Environ 2003; 26: 125 149.

295 Hilder V, Powell KS, Gatehouse AM et al. Expression of snowdrop lectin in transgenic tobacco plants results in added protection against aphids. Transgenic Res 1995; 4: 18-25.

296 Stoger E, Williams S, Christou P, Down RE, Gatehouse JA. Expression of the insecticidal lectin from snowdrop (Galanthus nivalis agglutinin; GNA) in transgenic wheat plants: effects on predation by the grain aphid Sitobion avenae. Mol Breed 1999; 5: 65-73.

297 Saha P, Majumder P, Dutta I, Ray T, Roy SC, Das S. Transgenic rice expressing Allium sativum leaf lectin with enhanced resistance against sap-sucking insect pests. Planta 2006; 223: 1329-1343.

298 Keller B, Baumgartner C. Vascular-specific expression of the bean GRP 1.8 gene is negatively regulated. Plant Cell 1991; 3: 1051-1061.

299 Liu YH, Jia SR. [Vascular-specific promoters and cis-regulatory elements]. Sheng Wu Gong Cheng Xue Bao 2003; 19: 131-135. Chinese.

300 Keller B, Schmid J, Lamb CJ. Vascular expression of a bean cell wall glycine-rich protein beta-glucuronidase gene fusion in transgenic tobacco. EMBO J 1989; 8: 1309-1314.

301 Leyva A, Liang X, Pintor-Toro JA, Dixon RA, Lamb CJ. cis-element combinations determine phenylalanine ammonia-lyase gene tissue-specific expression patterns. Plant Cell 1992; 4: 263-271.

302 Seguin A, Laible G, Leyva A, Dixon RA, Lamb CJ. Characterization of a gene encoding a DNA-binding protein that interacts in vitro with vascular specific cis elements of the phenylalanine ammonia-lyase promoter. Plant Mol Biol 1997; 35: 281-291.

303 de Azevedo FA, Mourão Filho FA, Schinor EH et al. GUS gene expression driven by a citrus promoter in transgenic tobacco and 'Valencia' sweet orange. Pesq Agropec Bras 2006; 41: 1623-1628.

304 Harakava, R. Citrus variegated chlorosis: development of transgenic resistance and molecular studies of pathogenesis. PhD thesis, University of Florida, Gainesville, FL, USA, 2000.

305 Brears T, Walker EL, Coruzzi GM. A promoter sequence involved in cell-specific expression of the pea glutamine synthetase GS3A gene in organs of transgenic tobacco and alfalfa. Plant J 1991; 1: 235-244.

306 Truernit E, Sauer N. The promoter of the Arabidopsis thaliana SUC2 sucrose- $\mathrm{H}^{+}$ symporter gene directs expression of $\beta$-glucuronidase to the phloem: evidence for phloem loading and unloading by SUC2. Planta 1995; 196: 564-570.

307 Dutt M, Ananthakrishnan G, Jaromin M, Brlansky R, Grosser J. Evaluation of four phloem-specific promoters in vegetative tissues of transgenic citrus plants. Tree Physiol 2012; 32: 83-93.

308 Miyata LY, Harakava R, Stipp LC et al. GUS expression in sweet oranges (Citrus sinensis L. Osbeck) driven by three different phloem-specific promoters. Plant Cell Rep 2012; 31: 2005-2013.

309 Sun Q, Zhao Y, Sun HY, Hammond RW, Davis RE, Xin L. High-efficiency and stable genetic transformation of pear (Pyrus communis L.) leaf segments and regeneration of transgenic plants. Acta Physiol Plant 2011; 33: 383-390.

310 Zhao Y, Liu Q, Davis RE. Transgene expression in strawberries driven by a heterologous phloem-specific promoter. Plant Cell Rep 2004; 23: 224-230.

311 Singer SD, Hily JM, Cox KD. The sucrose synthase-1 promoter from Citrus sinensis directs expression of the $\beta$-glucuronidase reporter gene in phloem tissue and in response to wounding in transgenic plants. Planta 2011; 234: 623-637.

312 Benyon L, Stover E, Bowman KD et al. GUS expression driven by constitutive and phloem-specific promoters in citrus hybrid US-802. In Vitro Cell Dev Biol Plant 2013; 49: $255-265$.

313 Gittins JR, Pellny TK, Biricolti S, Hiles ER, Passey AJ, James DJ. Transgene expression in the vegetative tissues of apple driven by the vascular-specific rolC and CoYMV promoters. Transgenic Res 2003; 12: 391-402.

314 Gatz C. Chemically inducible promoters in transgenic plants. Curr Opin Biotechnol 1996; 7: 168-172.

315 Zuo J, Chua NH. Chemical-inducible systems for regulated expression of plant genes. Curr Opin Biotechnol 2000; 11: 146-151.

316 Schena M, Lloyd AM, Davis RW. A steroid-inducible gene expression system for plant cells. Proc Natl Acad Sci USA 1991; 88: 10421-10425.

317 Vierling E. The roles of heat shock proteins in plants. Annu Rev Plant Biol 1991; 42 579-620.

318 Gatz C, Lenk I. Promoters that respond to chemical inducers. Trends Plant Sci 1998; 3: $352-358$

319 Coca MA, Almoguera C, Thomas TL, Jordano, J. Differential regulation of small heatshock genes in plants: analysis of a water-stress-inducible and developmentally activated sunflower promoter. Plant Mol Biol 1996; 31: 863-876.

320 Yamaguchi-Shinozaki K, Shinozaki K. Organization of cis-acting regulatory elements in osmotic-and cold-stress-responsive promoters. Trends Plant Sci 2005; 10: 88-94.

321 Weisshaar B, Armstrong GA, Block A, de Silva OD, Hahlbrock K. Light-inducible and constitutively expressed DNA-binding proteins recognizing a plant promoter element with functional relevance in light responsiveness. EMBO J 1991; 10: 1777.

322 Deeken R, Kaldenhoff R. Light-repressible receptor protein kinase: a novel photoregulated gene from Arabidopsis thaliana. Planta 1997; 202: 479-486.

323 Jacinto T, McGurl B, Franceschi V, Delano-Freier J, Ryan CA. Tomato prosystemin promoter confers wound-inducible, vascular bundle-specific expression of the $\beta$ glucuronidase gene in transgenic tomato plants. Planta 1997; 203: 406-412. 
324 Feuillet C, Lauvergeat V, Deswarte C, Pilate G, Boudet A, Grima-Pettenati J et al. Tissue-and cell-specific expression of a cinnamyl alcohol dehydrogenase promoter in transgenic poplar plants. Plant Mol Biol 1995; 27: 651-667.

325 Weinmann P, Gossen M, Hillen W, Bujard H, Gatz C. A chimeric transactivator allows tetracycline-responsive gene expression in whole plants. Plant J 1994; 5 559-569.

326 Martinez A, Sparks C, Hart CA, Thompson J, Jepson I. Ecdysone agonist inducible transcription in transgenic tobacco plants. Plant J 1999; 19: 97-106.

327 Rutherford JC, Bird AJ. Metal-responsive transcription factors that regulate iron, zinc, and copper homeostasis in eukaryotic cells. Eukaryot Cell 2004; 3: 1-13.

328 Uknes $\mathrm{S}$ et al. Regulation of pathogenesis-related protein-1a gene expression in tobacco. Plant Cell Online 1993; 5: 159-169.

329 Bryant J, Green TR, Gurusaddaiah T, Ryan CA. Proteinase inhibitor II from potatoes: isolation and characterization of its protomer components. Biochemistry 1976; 15 3418-3424.

330 Bergey DR, Howe GA, Ryan CA. Polypeptide signaling for plant defensive genes exhibits analogies to defense signaling in animals. Proc Natl Acad Sci USA 1996; 93 12053-12058.

331 Conconi A, Smerdon MJ, Howe GA, Ryan CA. The octadecanoid signalling pathway in plants mediates a response to ultraviolet radiation. Nature 1996; 383: 826-829.

332 Keil M, Sanchez-Serrano J, Schell J, Willmitzer L. Primary structure of a proteinase inhibitor II gene from potato (Solanum tuberosum). Nucleic Acids Res 1986; 14: 5641-5650.

333 Godard KA, Byun-McKay A, Levasseur C, Plant A, Séguin A, Bohlmann J. Testing of a heterologous, wound and insect-inducible promoter for functional genomics studies in conifer defense. Plant Cell Rep 2007; 26: 2083-2090.

334 Smigocki A, Neal JW Jr, McCanna I, Douglass L. Cytokinin-mediated insect resistance in Nicotiana plants transformed with the ipt gene. Plant Mol Biol 1993; 23: 325-335.

335 Xu D, McElroy D, Thornburg RW, Wu, R. Systemic induction of a potato pin2 promoter by wounding, methyl jasmonate, and abscisic acid in transgenic rice plants. Plant Mol Biol 1993; 22: 573-588.

336 Samac DA, Smigocki AC. Expression of oryzacystatin I and II in alfalfa increases resistance to the root-lesion nematode. Phytopathology 2003; 93: 799-804.

337 Godard KA, Byun-McKay A, Levasseur C, Plant A, Séguin A, Bohlmann J. Testing of a heterologous, wound- and insect-inducible promoter for functional genomics studies in conifer defense. Plant Cell Rep 2007; 26: 2083-2090.

338 Duan X, Li X, Xue Q et al. Transgenic rice plants harboring an introduced potato proteinase inhibitor II gene are insect resistant. Nat Biotechnol 1996; 14: 494-498.

339 Logemann J, Schell J. Nucleotide sequence and regulated expression of a woundinducible potato gene (wun1). Mol Gen Genet 1989; 219: 81-88.

340 Siebertz B, Logemann J, Willmitzer L, Schell J. cis-analysis of the wound-inducible promoter wun 1 in transgenic tobacco plants and histochemical localization of its expression. Plant Cell Online 1989; 1: 961-968.

341 Yi SY, Sun AQ, Sun Y et al. Differential regulation of Lehsp23. 8 in tomato plants: analysis of a multiple stress-inducible promoter. Plant Sci 2006; 171: 398-407.

342 Yi SY, Liu J. Combinatorial interactions of two cis-acting elements, AT-rich regions and HSEs, in the expression of tomato Lehsp23. 8 upon heat and non-heat stresses. J Plant Biol 2009; 52: 560-568.

343 Neta-Sharir I, Isaacson T, Lurie S, Weiss D. Dual role for tomato heat shock protein 21: protecting photosystem II from oxidative stress and promoting color changes during fruit maturation. Plant Cell Online 2005; 17: 1829-1838.

344 Almoguera C, Jordano J. Developmental and environmental concurrent expression of sunflower dry seed stored low molecular weight heat-shock protein and Lea mRNAs. Plant Mol Biol 1992; 19: 781-792.

345 Díaz-Martín J, Almoguera C, Prieto-Dapena P, Espinosa JM, Jordano J. Functional interaction between two transcription factors involved in the developmental regulation of a small heat stress protein gene promoter. Plant Physiol 2005 139: 1483-1494.

346 Coca MA, Almoguera C, Thomas TL, Jordano J. Differential regulation of small heatshock genes in plants: analysis of a water-stress-inducible and developmentally activated sunflower promoter. Plant Mol Biol 1996; 31: 863-876.

347 Escobar C, Barcala M, Portillo M, Almoguera C, Jordano J, Fenoll C. Induction of the Hahsp17.7G4 promoter by root-knot nematodes: involvement of heat-shock elements in promoter activity in giant cells. Mol Plant-Microbe Interact 2003; 16 1062-1068.

348 Barcala M, García A, Cubas P et al. Distinct heat-shock element arrangements that mediate the heat shock, but not the late-embryogenesis induction of small heatshock proteins, correlate with promoter activation in root-knot nematode feeding cells. Plant Mol Biol 2008; 66: 151-164.

349 Kim KY, Kwon SY, Lee HS, Hur Y, Bang JW, Kwak SS. A novel oxidative stressinducible peroxidase promoter from sweetpotato: molecular cloning and characterization in transgenic tobacco plants and cultured cells. Plant Mol Biol 2003; 51: 831-838.

350 Pino MT, Skinner JS, Park EJ et al. Use of a stress inducible promoter to drive ectopic AtCBF expression improves potato freezing tolerance while minimizing negative effects on tuber yield. Plant Biotechnol J 2007; 5: 591-604.

351 Bouquin T, Lasserre E, Pradier J, Pech JC, Balagué C. Wound and ethylene induction of the ACC oxidase melon gene CM-ACO1 occurs via two direct and independent transduction pathways. Plant Mol Biol 1997; 35: 1029-1035.

352 Ellard-lvey M, Douglas CJ. Role of jasmonates in the elicitor-and wound-inducible expression of defense genes in parsley and transgenic tobacco. Plant Physiol 1996; 112: $183-192$

353 Cao J, Shelton A, Earle E. Gene expression and insect resistance in transgenic broccoli containing a Bacillus thuringiensis cry1 $\mathrm{Ab}$ gene with the chemically inducible PR-1a promoter. Mol Breed 2001; 8: 207-216.

354 Coutos-Thévenot $\mathrm{P}$, Poinssot $\mathrm{B}$, Bonomelli $\mathrm{A}$ et al. In vitro tolerance to Botrytis cinerea of grapevine $41 \mathrm{~B}$ rootstock in transgenic plants expressing the stilbene synthase Vst1 gene under the control of a pathogen-inducible PR 10 promoter. $J$ Exp Botany 2001; 52: 901-910.

355 Laurance WF, Sayer J, Cassman KG. Agricultural expansion and its impacts on tropical nature. Trends Ecol Evol 2014; 29: 107-116.

356 Tilman D. Global environmental impacts of agricultural expansion: the need for sustainable and efficient practices. Proc Natl Acad Sci USA 1999; 96: 5995-6000.

357 Godfray HC, Beddington JR, Crute IR et al. Food security: the challenge of feeding 9 billion people. Science 2010; 327: 812-818.

358 Foley JA, Ramankutty N, Brauman KA et al. Solutions for a cultivated planet. Nature 2011; 478: 337-342.

359 Huang S. Global trade of fruits and vegetables and the role of consumer demand. In: Trade, Food, Diet and Health: Perspectives and Policy Options. Oxford: WileyBlackwell; 2010: 60-76.

$360 \mathrm{Liu} \mathrm{RH}$. Health benefits of fruit and vegetables are from additive and synergistic combinations of phytochemicals. Am J Clin Nutr 2003; 78: 517S-520S.

361 Liu RH. Potential synergy of phytochemicals in cancer prevention: mechanism of action. J Nutr 2004; 134: 3479S-3485S.

362 Barrows G, Sexton S, Zilberman D. Agricultural biotechnology: the promise and prospects of genetically modified crops. J Econ Perspect 2014; 28: 99-119.

363 Gonsalves C, Lee DR, Gonsalves D. The adoption of genetically modified papaya in Hawaii and its implications for developing countries 1. J Dev Stud 2007; 43: 177191.

364 Ferreira SA, Pitz KY, Manshardt R et al. Virus coat protein transgenic papaya provides practical control of papaya ringspot virus in Hawaii. Plant Dis 2002; 86: 101-105.

365 Tanaka Y, Brugliera, F, Chandler S. Recent progress of flower colour modification by biotechnology. Int J Mol Sci 2009; 10: 5350-5369.

366 Bradford K, Alston J, Lemaux P, Sumner D. Challenges and opportunities for horticultural biotechnology. Calif Agric 2004; 58: 68-71.

367 Mooney S. Bioinformatics approaches and resources for single nucleotide polymorphism functional analysis. Brief Bioinf 2005; 6: 44-56.

368 Lowe TM, Eddy SR. tRNAscan-SE: a program for improved detection of transfer RNA genes in genomic sequence. Nucleic Acids Res 1997; 25: 0955-0964.

369 Nagaraj SH, Gasser RB, Ranganathan S. A hitchhiker's guide to expressed sequence tag (EST) analysis. Brief Bioinf 2007; 8: 6-21.

370 Ashurst JL, Collins JE. Gene annotation: prediction and testing. Annu Rev Genomics Hum Genet 2003; 4: 69-88.

371 Portales-Casamar E, Thongjuea S, Kwon AT et al. JASPAR 2010: the greatly expanded open-access database of transcription factor binding profiles. Nucleic Acids Res 2009; 38(Database issue): D105-D110.

372 Espinoza $C$ et al. Cisgenesis and intragenesis: new tools for improving crops. Biol Res 2013; 46: 323-331.

373 Holme IB, Wendt T, Holm PB. Intragenesis and cisgenesis as alternatives to transgenic crop development. Plant Biotechnol J 2013; 11: 395-407.

374 Nielsen KM. Transgenic organisms-time for conceptual diversification? Nat Biotechnol 2003; 21: 227-228.

375 Gray DJ, Li ZT, Dhekney SA. Precision breeding of grapevine (Vitis vinifera L.) for improved traits. Plant Sci 2014; in press.

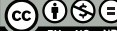

This work is licensed under a Creative Commons Attribution

NonCommercial-NoDerivs 3.0 Unported License. The images or other third party material in this article are included in the article's Creative Commons license, unless indicated otherwise in the credit line; if the material is not included under the Creative Commons license, users will need to obtain permission from the license holder to reproduce the material. To view a copy of this license, visit http:// creativecommons.org/licenses/by-nc-nd/3.0/ 